\title{
Age of Tertiary volcanic rocks on the West Greenland continental margin: volcanic evolution and event correlation to other parts of the North Atlantic Igneous Province
}

\author{
LOTTE M. LARSEN*†, ASGER K. PEDERSEN* ${ }_{\ddagger}^{*}$, CHRISTIAN TEGNER $\S$, \\ ROBERT A. DUNCAN\|, NIELS HALD $\ddagger$ JØRGEN G. LARSEN \\ * Geological Survey of Denmark and Greenland, Øster Voldgade 10, DK-1350 Copenhagen K, Denmark \\ $\ddagger$ †atural History Museum of Denmark, Øster Voldgade 5-7, DK-1350 Copenhagen K, Denmark \\ §Department of Geoscience, Aarhus University, Høegh-Guldbergs Gade 2, DK-8000 Aarhus C, Denmark \\ \|College of Earth, Ocean and Atmospheric Sciences, Oregon State University, Corvallis, Oregon 97331, USA \\ 『Rønnekrogen 18, DK-2880 Bagsværd, Denmark
}

(Received 5 March 2015; accepted 23 June 2015; first published online 13 August 2015)

\begin{abstract}
Radiometric ages for undated parts of the volcanic succession and intrusions in West Greenland were obtained by the ${ }^{40} \mathrm{Ar}-{ }^{39} \mathrm{Ar}$ incremental heating method. Acceptable crystallization ages were obtained for 27 samples. Combined with published results the new data provide a volcanic stratigraphy correlatable throughout the Nuussuaq Basin. The thick onshore volcanic pile consists of four widespread formations: 62.5-61 Ma picrites (Vaigat Formation), 61-60 Ma depleted basalts (Maligât Formation and the Hellefisk-1 well), 60-58 Ma less-depleted basalts (Svartenhuk Formation) and 56-54 Ma enriched basalts (Naqerloq Formation). Two local successions comprise 53.5 Ma alkali basalts (Erqua Formation) and 38.7 Ma transitional basalts (Talerua Member). A central volcano developed on Ubekendt Ejland, leading to the Sarqâta qáqâ gabbro-granophyre intrusion at 57-55 Ma. Pre-break-up volcanism took place further south as early as 64-63 Ma. The offshore volcanic succession most probably comprises the known onshore succession plus some younger lavas. The change in spreading direction near the Paleocene-Eocene boundary took place west of the Nuussuaq Basin c. 56.2 Ma. Some tectonomagmatic events are correlatable across the entire North Atlantic Igneous Province. A quiescent 58-56 Ma period correlates with similar periods in East Greenland and the Faroes, and the Naqerloq Formation is coeval with the Eocene basalts in East Greenland. The Paleocene and Eocene tholeiitic basalts are distinguishable chemically; in early Eocene time, mantle typical of the Iceland plume seems to have extended beneath the whole West Greenland margin as well as the central East Greenland margin.
\end{abstract}

Keywords: West Greenland Basalt Group, Tertiary, radiometric dating, flood basalts, intrusions, volcanic stratigraphy, North Atlantic Igneous Province.

\section{Introduction}

The Tertiary volcanic rocks in West Greenland form part of the North Atlantic Igneous Province, which extends for more than $3000 \mathrm{~km}$ from Baffin Island over West Greenland and East Greenland to Iceland, the Faroes, Ireland and Scotland. The magmas were emplaced during a number of tectonomagmatic events closely associated with lithospheric stretching, continental break-up and formation of the North Atlantic Ocean. The events have been associated with the arrival of a hot mantle plume beneath the lithosphere (e.g. Upton, 1988; Eldholm \& Grue, 1994; Saunders et al. 1997), whereas the existence of a mantle plume has been contended by others, e.g. Foulger \& Anderson (2005) and Lundin \& Doré (2005). Notwithstanding the plume discussion, there is general agreement that plate tectonic processes together with extraordinarily voluminous volcanism played an important role in

${ }^{\dagger}$ Author for correspondence: 1ml@geus.dk the shaping of the North Atlantic continental margins and seas.

In order to understand the processes and development of the North Atlantic it is important to know the age of the various volcanic successions and intrusions. The volcanic rocks are almost exclusively potassium-poor basalts, which are difficult to date, but the ages of most onshore successions are now reasonably well known, as summarized by Storey, Duncan \& Tegner (2007) for central East Greenland and the Faroes, Brown, Holohan \& Bell (2009) for Scotland and Larsen et al. (2014) for northern East Greenland. The West Greenland volcanic areas form the second largest onshore Tertiary succession in the North Atlantic, extending for c. $400 \mathrm{~km} \mathrm{~N}-\mathrm{S}$ and $125 \mathrm{~km} \mathrm{~W}-\mathrm{E}$, i.e. over c. $50000 \mathrm{~km}^{2}$. Storey et al. (1998) dated the southern part of the succession whereas the northern part has remained largely undated.

This work presents precise radiometric ages for the hitherto undated parts of the volcanic succession in West Greenland together with ages for some dykes 
and sills and the only known central complex in the region. It provides an update of the volcanic stratigraphy and basin-wide correlation that yields a much more complete overview of the age distribution and stratigraphy of the igneous rocks along the West Greenland margin. This allows for extended timeand event-correlation to the more easterly parts of the North Atlantic Igneous Province.

In this work, quotations of earlier published age results based on the Fish Canyon Tuff standard are recalculated to an age of 28.201 Ma for the Fish Canyon Tuff standard, following the Geologic Time Scale 2012 (GTS 2012; Gradstein et al. 2012). Numerical intervals for magnetic polarity chrons also follow the GTS 2012 (Vandenberghe, Hilgen \& Speijer, 2012). All ages are quoted with $2 \sigma$ uncertainty.

\section{Tectonomagmatic development of the West Greenland margin}

Lithospheric stretching between Canada and West Greenland was under way in early Cretaceous time (review by Chalmers \& Pulvertaft, 2001) and most probably started in Jurassic time (Larsen et al. 2009). The rift to drift transition, however, only started in Paleocene time, magnetic polarity chron $\mathrm{C} 27 \mathrm{n}$ (62.5-62.2 Ma), based on the identification of C27n as the earliest linear magnetic anomaly in the Labrador Sea (Chalmers \& Laursen, 1995; Chalmers \& Pulvertaft, 2001; Keen, Dickie \& Dehler, 2012; Oakey $\&$ Chalmers, 2012). Break-up apparently took place simultaneously in the Labrador Sea and Baffin Bay, which were linked by a complex zone of transtension and transpression and faulting (Oakey \& Chalmers, 2012); the Davis Strait High is part of this zone and contains a continental sliver (Fig. 1). In earliest Eocene time (c. $56 \mathrm{Ma}$ ), the main break-up in the North Atlantic between East Greenland and Europe started. Around the same time the spreading in the Labrador Sea and Baffin Bay changed direction from WSW-ENE to S-N; this change was diachronous, the time varying from magnetic polarity chron $\mathrm{C} 25 \mathrm{n}$ (57.7-57.1 Ma) in the south to C24n (54.0-52.6) in the north (Oakey \& Chalmers, 2012). After chron C21 (c. $45 \mathrm{Ma}$ ) seafloor spreading slowed down and stopped altogether in Oligocene time around chron C12-C13, c. $33 \mathrm{Ma}$ (Roest \& Srivastava, 1989).

Tertiary volcanic rocks occur on both the Greenland and Canada margins of the Labrador Sea and Baffin Bay. The West Greenland margin comprises volcanic rocks between $63^{\circ} \mathrm{N}$ and $73^{\circ} \mathrm{N}$; the major parts of these are situated on the shelf or under deep water and are partly or completely covered by younger sediments (Fig. 1); they are therefore not well known. Seismic studies in the northern Labrador Sea, Davis Strait and southern Baffin Bay have revealed the existence of extensive Palaeogene volcanic rocks (Whittaker, 1996; Skaarup, 2002; Skaarup, Jackson \& Oakey, 2006; Gregersen \& Bidstrup, 2008; Keen, Dickie \& Dehler, 2012) and a several kilometres thick magmatic underplate, interpreted as plume-generated, beneath the thinned lithosphere (Funck et al. 2007, 2012; Keen, Dickie \& Dehler, 2012). On the Greenland side, a scarcity of volcanic rocks between $66^{\circ} \mathrm{N}$ and $67^{\circ} 30^{\prime} \mathrm{N}$ separates the volcanic parts into a southern and a northern area. In the southern area the Hecla High and Maniitsoq High are the two largest of a number of individual volcanic centres and seamounts on the Greenland shelf (Sørensen, 2006; Oakey \& Chalmers, 2012). The northern area houses a thick and extensive volcanic succession whose southernmost part is up to $4 \mathrm{~km}$ thick (Funck et al. 2012). This volcanic succession is exposed onshore in the Nuussuaq Basin between $69^{\circ} 15^{\prime} \mathrm{N}$ and $73^{\circ} \mathrm{N}$ on Disko, Nuussuaq, Ubekendt Ejland, Svartenhuk Halvø and in inland areas further north (Fig. 2).

\section{The Nuussuaq Basin}

The rocks in the Nuussuaq Basin (Fig. 2) comprise up to $6-8 \mathrm{~km}$ of Cretaceous to Paleocene fluvio-deltaic to marine sandstones and shales of the Nuussuaq Group (Dam et al. 2009). The Nuussuaq Group is overlain by a thick volcanic succession with relatively thin intervals of intra-volcanic sediments (Henderson, Rosenkrantz \& Schiener, 1976; Henderson et al. 1981; Clarke \& Pedersen, 1976; see overview by Henriksen et al. 2009). The thickness of the volcanic succession is greatest on Ubekendt Ejland where up to $10 \mathrm{~km}$ of volcanic rocks may be present (Larsen, 1977a); on Svartenhuk Halvø there is up to $c .7 \mathrm{~km}$ of succession present (Larsen \& Pulvertaft, 2000) although intense faulting may have caused undetected repetitions in the stratigraphy; and on Disko and Nuussuaq thicknesses are up to more than $5 \mathrm{~km}$ (Larsen \& Pedersen, 2009). The volcanic lithologies comprise mainly marine and non-marine hyaloclastite deposits and subaerial lava flows. Dykes are frequent, sills are few, and there is only one central intrusive complex, which is situated on Ubekendt Ejland.

The Nuussuaq Basin is bounded towards the Precambrian gneiss highland in the east by a large fault system, the Eastern Boundary Fault system (Fig. 2). Another important fault is the NE-SW-oriented Itilli Fault through Hareøen and westernmost Nuussuaq; owing to kilometre-scale downthrow to the northwest, a very different and mainly younger volcanic succession is preserved west of this fault. While the eastern and central parts of the volcanic areas are subhorizontal, the western areas comprise a number of fault blocks in which the volcanic succession generally dips seawards, i.e. to the west on Disko and parts of Nuussuaq, to the northwest on westernmost Nuussuaq, and to the southwest on Svartenhuk Halvø. Ubekendt Ejland is a pivot area through which the dips change from NW to SW, giving the succession a bowl-shaped synclinal structure with the youngest rocks at the westernmost point. These structural features continue on the shelf where they are clearly seen in the aeromagnetic data for the region (Rasmussen, 2002). 


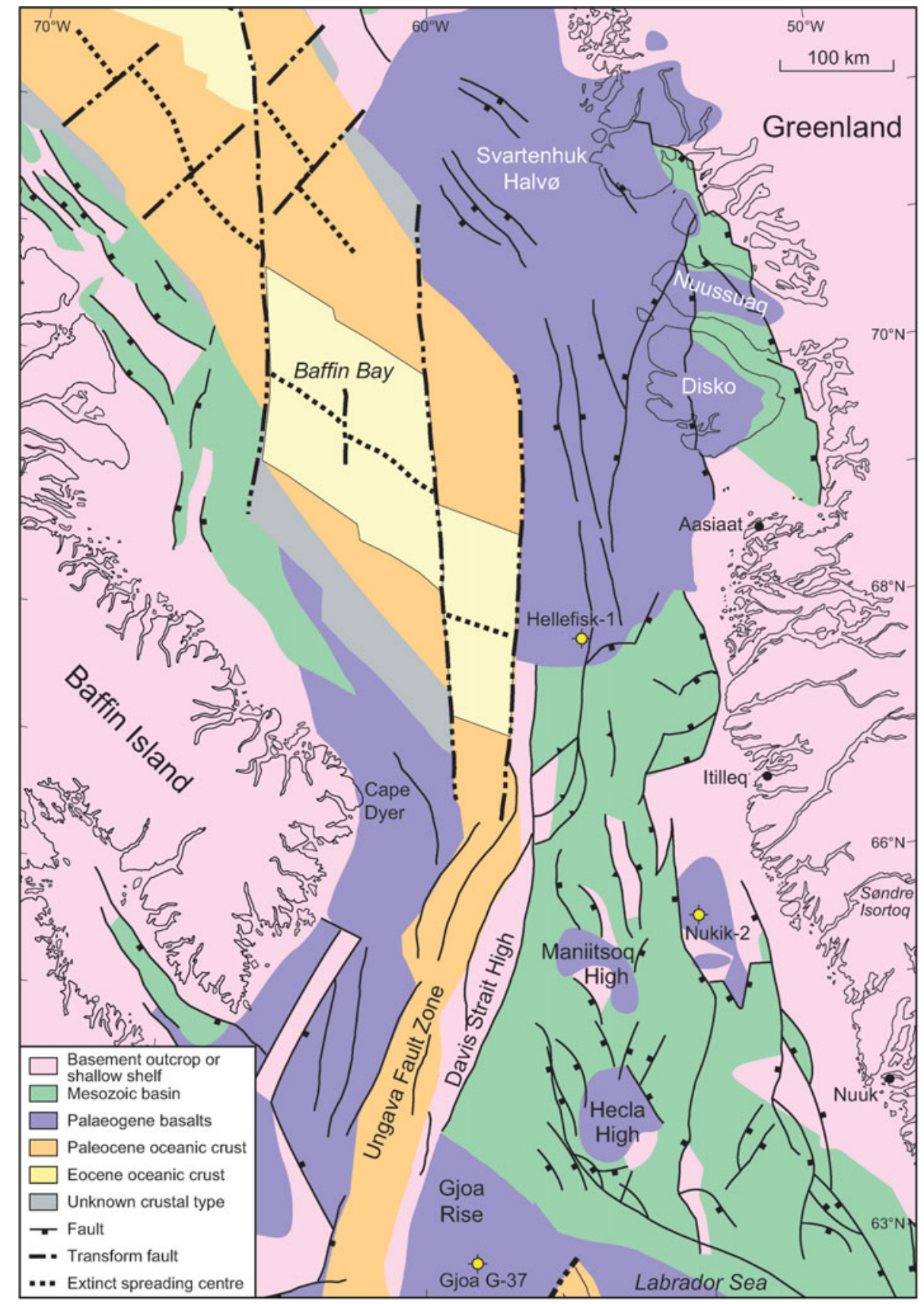

Figure 1. Geological and structural overview map modified from Oakey \& Chalmers (2012) and Funck et al. (2012).

The main volcanic succession on Disko and Nuussuaq has been dated to Paleocene, 62-60 Ma by Storey et al. (1998) who also identified an early Eocene succession in westernmost Nuussuaq. Scattered dykes and small intrusions have likewise indicated younger igneous activity (Storey et al. 1998; Larsen et al. 2009), but the possible extent and ages of both Paleocene and younger rocks have been unknown because the northern areas were undated.

\section{3.a. Volcanic stratigraphy}

From Disko to Svartenhuk Halvø the volcanic succession consists of a lower part dominated by picrites and an upper part dominated by basalts. The picritic suc- cession is formalized as the Vaigat Formation (Hald $\&$ Pedersen, 1975). The basalts of the upper part have been referred to different formations and members in the different areas, and correlation between these has not hitherto been possible. Based on the present dating results an overall correlation can now be suggested, as shown in Figure 3. This figure also shows the previously published and the new radiometric age data.

The volcanic stratigraphy established by Hald \& Pedersen (1975) was centred on Disko and Nuussuaq where the Vaigat Formation is overlain by the basaltic Maligât Formation. The basalts on Ubekendt Ejland were referred to the Maligât Formation by Larsen (1977a). The basalts on Svartenhuk Halvø have been referred to the Svartenhuk Formation (Larsen \& Grocott, 1991; 


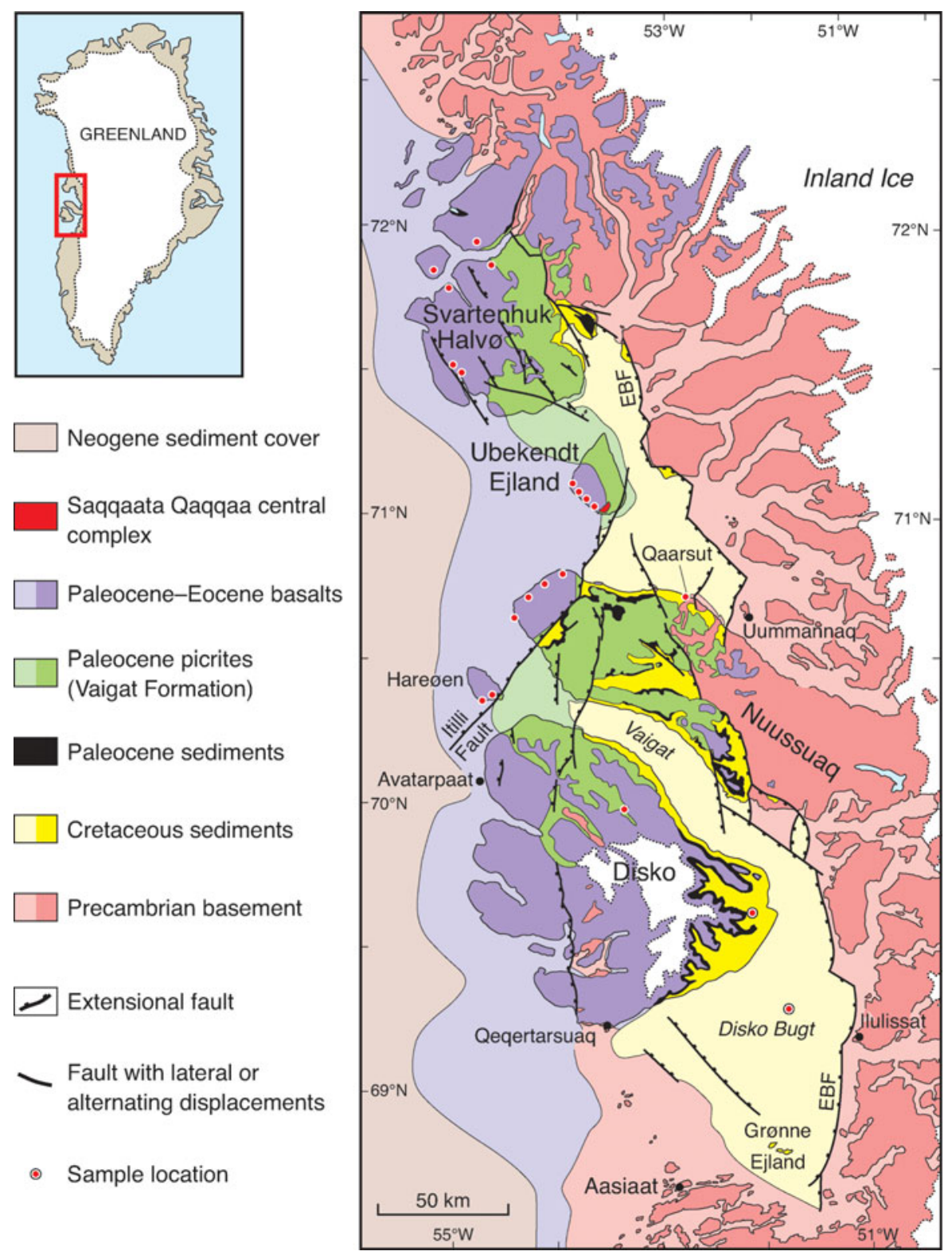

Figure 2. Geological map of the Nuussuaq Basin, with sample sites indicated. The light colour shades are sea-covered areas.

Larsen \& Pulvertaft, 2000), which has been assumed to be equivalent to the Maligât Formation. The revised stratigraphic scheme in Figure 3 places the Svartenhuk Formation in the Paleocene above the Maligat Formation, and a new formation, the Naqerloq Formation, is introduced to overcome the problem that the Svartenhuk and Maligât formations as originally defined both comprised Paleocene and Eocene parts with a hiatus between them. As will be mentioned later, there are also geochemical differences between the formations.

\section{Analytical methods}

Samples were dated by using the ${ }^{40} \mathrm{Ar}-{ }^{39} \mathrm{Ar}$ incremental heating method in the Noble Gas Mass Spectrometry Laboratory at Oregon State University. Unaltered phenocrysts were separated by standard mineral separation techniques. Fine-grained, unaltered whole-rock samples were cored with a $5 \mathrm{~mm}$ diameter diamondtipped drill bit and sectioned into discs of 100-300 mg, then irradiated at the Oregon State University TRIGA experimental reactor for six hours at $1 \mathrm{MW}$ power. The neutron flux was monitored with the FCT-3 biotite monitor. All ages are here calculated relative to an age of 28.201 Ma for the Fish Canyon Tuff, following Kuiper et al. (2008) and Schmitz (2012), and using the corrected decay constant for ${ }^{40} \mathrm{~K}$ of $5.53 \pm 0.097 \times$ $10^{-10} \mathrm{yr}^{-1}$ as reported by Min et al. (2000).

Samples were analysed with a MAP 215-50 gas mass spectrometer with all-metal extraction system equipped with a $10 \mathrm{~W} \mathrm{CO}_{2}$ laser and a Heine low-blank, doublevacuum resistance furnace connected to an ultra-clean, low volume $(\sim 1000 \mathrm{cc})$ gas cleanup line. Samples were degassed in 8-17 temperature steps, from $500^{\circ} \mathrm{C}$ to fusion at $c .1400^{\circ} \mathrm{C} . \mathrm{Zr}-\mathrm{Al}$ getters, at $21^{\circ}$ and $400^{\circ} \mathrm{C}$, removed active gases. Ion beam currents are measured 


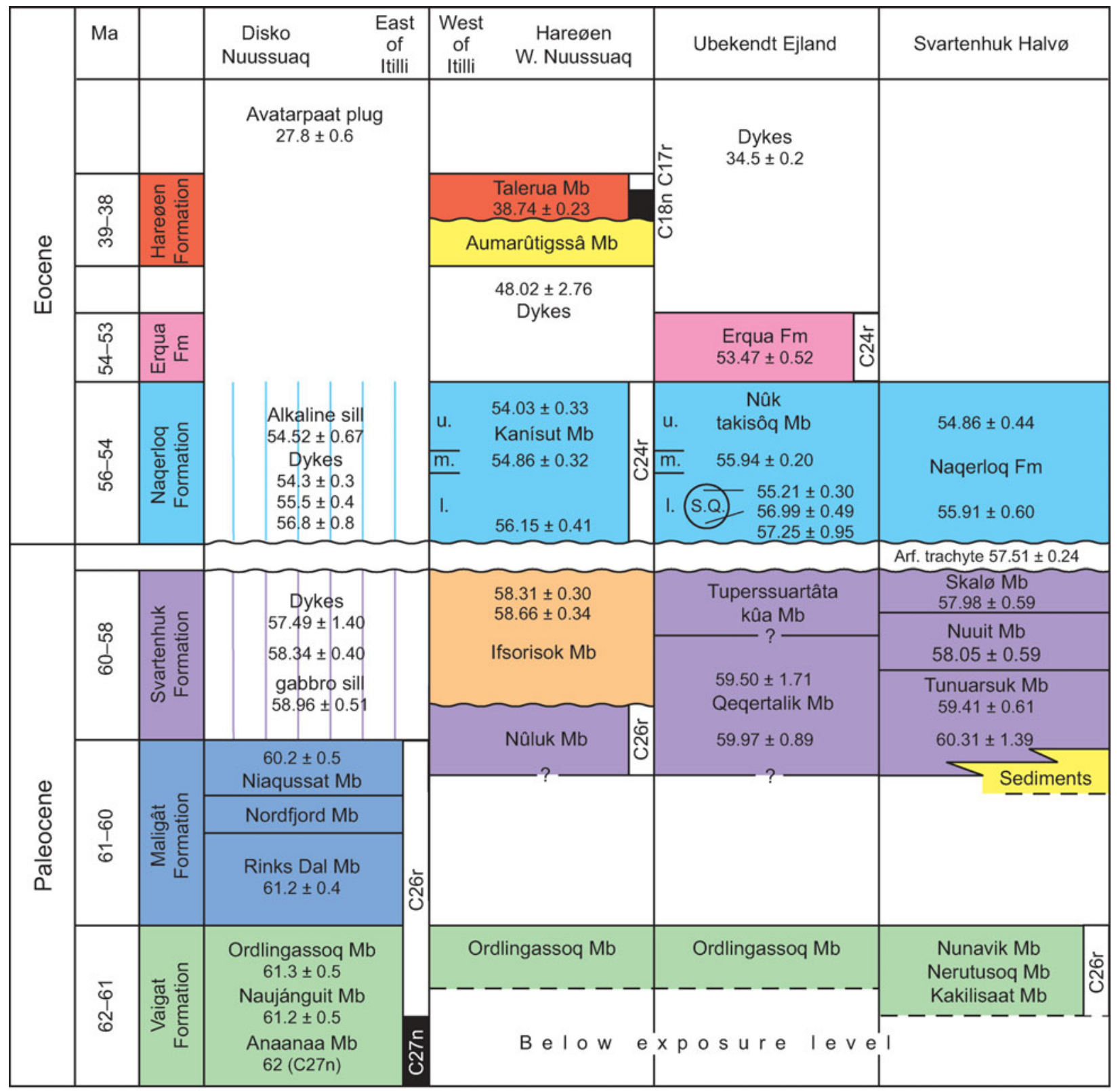

Figure 3. Stratigraphic scheme for the volcanic rocks in the Nuussuaq Basin. Based on Hald \& Pedersen (1975) for Disko and Nuussuaq, Hald (1976) for Hareøen and western Nuussuaq, Larsen (1977a) for Ubekendt Ejland, and Larsen \& Grocott (1991) and Larsen \& Pulvertaft (2000) for Svartenhuk Halvø. Tunuarsuk Member to Naqerloq Formation correspond to the mapped $\beta_{1}-\beta_{4}$ basalt units in Larsen \& Grocott (1991), which will be described elsewhere. S.Q - Sarqâta qáqâ central complex; 1. - lower; m. middle; u. - upper; yellow - sediments with a quartzo-feldspathic component; brown - purely volcaniclastic sediments; wavy lines unconformities. Narrow black and white columns at the right side of some lithological columns are palaeomagnetic directions, with magnetochrons indicated, from Riisager \& Abrahamsen (1999), Riisager et al. (1999, 2003), Schmidt et al. (2005) and unpub. data by P. Riisager. Radiometric ages (Ma) with two digits after the decimal point are from this work, and ages with one digit after the decimal point are from Storey et al. (1998) and Larsen et al. (2009). The age for the Anaanaa Member is not radiometric but based on its normally magnetized character. Note that the vertical 'age scale' is not equidistant (compare Fig. 9 for an equidistant age scale).

with the electron multiplier at $\mathrm{m} / \mathrm{z}=36,37,38,39$, 40 , and intervening baselines (half-way between the masses). Measurement times, peak/baseline voltages and data acquisition are computer controlled. Mass discrimination is monitored using an air pipette system. All resulting ages are calculated using the ArArCALC software package (Koppers, 2002).

One age was obtained using the multi-collector ARGUS-VI mass spectrometer with five Faraday col- lectors (all fitted with $10^{12} \mathrm{Ohm}$ resistors) and one ioncounting $\mathrm{CuBe}$ electron multiplier (located in a position next to the lowest mass Faraday collector). This allows simultaneous measurement of all argon isotopes, with mass 36 on the multiplier and masses 37 through 40 on the four adjacent Faraday collectors. In this case, we heated the sample in 36 steps using a $25 \mathrm{~W} \mathrm{CO}_{2}$ laser. All other aspects of the analytical procedure followed the description above. 


\section{Sample selection and results}

Basaltic samples for dating were selected based on a combination of petrography (unaltered plagioclase phenocrysts) and bulk chemical composition (highest possible $\mathrm{K}_{2} \mathrm{O}$ and undisturbed $\mathrm{K}_{2} \mathrm{O} / \mathrm{P}_{2} \mathrm{O}_{5}$ ratios). From aphyric units the most coarse-grained unaltered samples were chosen in order to minimize ${ }^{39} \mathrm{Ar}$ recoil problems. Evolved samples were selected based on the petrography of the alkali feldspar (freshness, homogeneity). Except for local areas, avoided in the sample selection, the volcanic succession in West Greenland is in the low-temperature zeolite facies and the Kanísut Member is even in the no-zeolites zone (Neuhoff et al. 2006).

A total of 39 samples were analysed. Of these, eight samples failed to yield a plateau or isochron and a few samples yielded poor plateaus that do not fulfil the usual criteria for acceptable ages (the ages of at least three consecutive steps comprising at least $50 \%$ of the released ${ }^{39} \mathrm{Ar}$ should be within $2 \sigma$ of each other). One result (included in Table 1) is apparently good but produces a geological conflict. We have accepted the ages of 27 samples; the data for these are summarized in Table 1, and details of the results, compositions and locations, together with a compilation of radiometric age determinations for Tertiary igneous rocks in West Greenland, are provided in the online Supplementary Material available at http://journals.cambridge.org/geo.

\section{5.a. Hellefisk-1 well in the offshore area}

The Hellefisk-1 well was drilled in 1977 near the southern limit of the offshore volcanic area between $67^{\circ} 30^{\prime} \mathrm{N}$ and $73^{\circ} \mathrm{N}$ (Fig. 1). The well penetrated $694 \mathrm{~m}$ of basalts $2507-3201 \mathrm{~m}$ below the rotary table (brt), and c. 35 subaerial lava flows with thicknesses of 5$50 \mathrm{~m}$ were identified from cuttings and sonic logs (Hald \& Larsen, 1987). The well terminated in basalt. For this work, we selected two samples of cuttings from the middle part of the basalt succession at 2889.5 and $2938.3 \mathrm{~m}$ brt.

\section{5.a.1. Results}

The two samples both gave good plateaus and ages within the uncertainty of each other: $59.69 \pm 1.33 \mathrm{Ma}$ and $61.34 \pm 1.16 \mathrm{Ma}$ (Fig. 4), with a weighted average of $60.63 \pm 0.87 \mathrm{Ma}$. Considering that all the Hellefisk-1 lavas have very low potassium contents (0.16-0.18 wt \% $\mathrm{K}_{2} \mathrm{O}$ in the dated samples), the results are good. They are also in accord with the age of the sediments that immediately overlie the basalts; these are of late Selandian age (Nøhr-Hansen, 2003), corresponding to 60-59 Ma (Vandenberghe, Hilgen \& Speijer, 2012).

\section{5.b. Disko and Nuussuaq east of the Itilli Fault}

In this area, the Vaigat Formation is up to $1.6 \mathrm{~km}$ thick and comprises three major picritic members (Fig. 3) and a number of minor members with contrasting compositions and colours that form marker horizons within the major members (Pedersen, 1985). The Vaigat Formation thins southwards and peters out in central Disko. The overlying basaltic Maligât Formation is locally more than $1700 \mathrm{~m}$ thick and consists of three members (Fig. 3). It is thickest in western Disko and thins northwards because it onlaps the Vaigat Formation. The most recent detailed stratigraphy for this area (east of the Itilli Fault) is given by Larsen \& Pedersen (2009).

The age of the volcanic succession in the Disko-Nuussuaq area is well known. Storey et al. (1998) dated the middle and upper Vaigat Formation to $61.1 \pm 1.0 \mathrm{Ma}$ to $61.5 \pm 1.0 \mathrm{Ma}$. Age results for the Maligât Formation were $61.1 \pm 0.8 \mathrm{Ma}$ to $61.3 \pm 0.8 \mathrm{Ma}$ for the lower part and $60.2 \pm 1.0 \mathrm{Ma}$ for the uppermost part. The lowest part of the Vaigat Formation could not be dated owing to low potassium contents, but it is normally magnetized and is referred to magnetic polarity chron C27n (62.5-62.2 Ma) (Riisager \& Abrahamsen, 1999). The rest of the Vaigat Formation and the overlying Maligât Formation are reversely magnetized and erupted during C26r (62.259.2 Ma) (Riisager \& Abrahamsen, 1999). No further samples from this part of the succession were dated in the present work.

The volcanic succession on Disko and Nuussuaq is cut by many basalt dykes, and the Eastern Boundary Fault system is intruded by thick dykes, sheets and sills. Apart from some silica-rich dykes, most dykes have normal basaltic compositions, which, however, do not match any lavas of the surrounding Maligât Formation. These dykes comprise two compositional groups, lowpotassium basalts similar to lavas of the Svartenhuk Formation, and enriched tholeiitic basalts similar to lavas of the Naqerloq Formation (unpub. data). Some dykes from both groups cut the whole volcanic succession. Two dykes and a sill, all of enriched tholeiitic basalt, have ages in the interval 56-54 Ma (Storey et al. 1998; Larsen et al. 2009). For this study, we selected two low-potassium basalt dykes from Disko; one of them cuts the entire succession.

The aeromagnetic map of West Greenland (Rasmussen, 2002) shows a number of rounded, strongly magnetic features in Disko Bugt, which have been interpreted as sills intruded into Cretaceous sediments, similar to the sill exposed on Grønne Ejland in the southern part of Disko Bugt (Fig. 2). A dredge haul over one of these features $30 \mathrm{~km}$ SE of Disko brought up many large coarse gabbroic blocks and no glacial erratics (Larsen \& Dalhoff, 2007). The gabbro is considered to represent a local sill. Its composition is similar to many low-potassium dykes on Disko, and it was included in the present dating programme.

A large sill at Qaarsut on the north coast of Nuussuaq is emplaced into Cretaceous sediments beneath the 
Table 1. ${ }^{40} \mathrm{Ar}-{ }^{39} \mathrm{Ar}$ ages for lavas and intrusions from West Greenland

\begin{tabular}{|c|c|c|c|c|c|c|c|c|c|}
\hline & Sample no. & $\begin{array}{l}\text { Latitude } \\
\text { Deg. N }\end{array}$ & $\begin{array}{l}\text { Longitude } \\
\text { Deg. W }\end{array}$ & Material & $\begin{array}{l}\text { Plateau age } \\
\pm 2 \sigma \text { (Ma) }\end{array}$ & $\%{ }^{39} \mathrm{Ar}$ & $\begin{array}{l}\text { Isochron age } \\
\pm 2 \sigma \text { (Ma) }\end{array}$ & MSWD & $\begin{array}{c}{ }^{40} \mathrm{Ar}-{ }^{36} \mathrm{Ar} \\
\text { Intercept }\end{array}$ \\
\hline \multicolumn{10}{|l|}{ Hareøen Formation, Hareøen } \\
\hline Talerua Mb (2013) & 113482 & $70^{\circ} 23.44^{\prime}$ & $54^{\circ} 44.76^{\prime}$ & Groundmass & $38.90 \pm 0.23$ & 77.0 & $38.90 \pm 0.28$ & 2.23 & $293 \pm 58$ \\
\hline Talerua Mb (2004) & 113482 & $70^{\circ} 23.44^{\prime}$ & $54^{\circ} 44.76^{\prime}$ & Groundmass & $38.57 \pm 0.24$ & 80.0 & $38.77+0.28$ & 2.27 & $236 \pm 59$ \\
\hline \multicolumn{10}{|l|}{ Dykes and sills } \\
\hline Dyke, W. Nuussuaq & 135129 & $70^{\circ} 45.62^{\prime}$ & $54^{\circ} 12.52^{\prime}$ & Plagioclase & $48.02 \pm 2.76$ & 100 & $46.77 \pm 2.84$ & 1.10 & $297 \pm 2$ \\
\hline Qaarsut sill, N. Nuussuaq* & 402581 & $70^{\circ} 43.07^{\prime}$ & $52^{\circ} 41.82^{\prime}$ & Feldspar & $51.63 \pm 0.29$ & 73.5 & $51.49 \pm 0.42$ & 0.83 & $297 \pm 4$ \\
\hline Alkaline sill, N. Nuussuaq & 489154 & $70^{\circ} 40.59^{\prime}$ & $52^{\circ} 41.75^{\prime}$ & Plagioclase & $54.52 \pm 0.67$ & 92.1 & $54.60 \pm 0.72$ & 0.61 & $293 \pm 8$ \\
\hline Dyke, northern Disko & 332904 & $69^{\circ} 57.55^{\prime}$ & $53^{\circ} 18.68^{\prime}$ & Whole-rock & $57.49 \pm 1.40$ & 21.9 & $57.43 \pm 2.59$ & 0.23 & $296 \pm 23$ \\
\hline Dyke, eastern Disko & 318800 & $69^{\circ} 39.73^{\prime}$ & $52^{\circ} 09.12^{\prime}$ & Plagioclase & $58.34 \pm 0.40$ & 99.3 & $58.41 \pm 0.86$ & 0.12 & $293 \pm 23$ \\
\hline Gabbro SE of Disko & 148D-01 & $69^{\circ} 18.67^{\prime}$ & $51^{\circ} 36.57^{\prime}$ & Plagioclase & $58.96 \pm 0.51$ & 81.0 & $58.47 \pm 1.65$ & 1.27 & $300 \pm 13$ \\
\hline \multicolumn{10}{|c|}{ Volcanic succession on Svartenhuk Halvø } \\
\hline Naqerloq Fm & 251372 & $71^{\circ} 50.9^{\prime}$ & $55^{\circ} 36.7^{\prime}$ & Plagioclase & $54.86 \pm 0.44$ & 93.4 & $54.52 \pm 0.92$ & 0.19 & $306 \pm 25$ \\
\hline Naqerloq Fm & 278596 & $71^{\circ} 31.5^{\prime}$ & $55^{\circ} 17.5^{\prime}$ & Plagioclase & $55.91+0.60$ & 78.8 & $55.02 \pm 7.91$ & 0.06 & n.d. \\
\hline Arfertuarsuk trachyte flow & 1931.1 & $71^{\circ} 30.1^{\prime}$ & $55^{\circ} 14^{\prime}$ & Anorthoclase & $57.51 \pm 0.24$ & 79.6 & $57.49 \pm 0.24$ & 4.51 & $300 \pm 7$ \\
\hline Skalø Mb & 262838 & $71^{\circ} 47.2^{\prime}$ & $55^{\circ} 22.9^{\prime}$ & Plagioclase & $57.98 \pm 0.59$ & 97.7 & $58.16 \pm 1.05$ & 0.06 & $285 \pm 52$ \\
\hline Nuuit $\mathrm{Mb}$ & 262773 & $71^{\circ} 58.6^{\prime}$ & $54^{\circ} 59.0^{\prime}$ & Plagioclase & $58.05 \pm 0.59$ & 95.3 & $58.22 \pm 1.13$ & 0.15 & $285 \pm 64$ \\
\hline Tunuarsuk $\mathrm{Mb}$ & 278566 & $71^{\circ} 53.0^{\prime}$ & $54^{\circ} 58.6^{\prime}$ & Whole-rock & $59.41 \pm 0.61$ & 69.0 & $59.88 \pm 1.20$ & 0.33 & $290 \pm 11$ \\
\hline Tunuarsuk Mb & 278578 & $71^{\circ} 53.1^{\prime}$ & $54^{\circ} 58.6^{\prime}$ & Whole-rock & $60.31 \pm 1.39$ & 65.4 & $62.85 \pm 8.96$ & 2.31 & $294 \pm 6$ \\
\hline \multicolumn{10}{|c|}{ Volcanic succession and central intrusion on Ubekendt Ejland } \\
\hline Erqua Formation & 438728 & $71^{\circ} 06.08^{\prime}$ & $53^{\circ} 57.68^{\prime}$ & Whole-rock & $53.47 \pm 0.52$ & 95.5 & $53.05 \pm 0.62$ & 0.65 & $317 \pm 19$ \\
\hline Sarqâta qáqâ granophyre & 417747 & $71^{\circ} 02.69^{\prime}$ & $53^{\circ} 39.61^{\prime}$ & Alkali feldspar & $55.21 \pm 0.30$ & 90.6 & $54.97 \pm 0.34$ & 2.27 & $299 \pm 3$ \\
\hline Sarqâta qáqâ gabbro & 455754 & $71^{\circ} 02.15^{\prime}$ & $53^{\circ} 41.27^{\prime}$ & Plagioclase & $56.99 \pm 0.49$ & 94.4 & $56.95 \pm 0.71$ & 1.84 & $298 \pm 27$ \\
\hline Nûk takisôq Mb & 438740 & $71^{\circ} 05.36^{\prime}$ & $53^{\circ} 54.55^{\prime}$ & Feldspar & $55.94 \pm 0.20$ & 93.8 & $55.69 \pm 0.39$ & 1.56 & $391 \pm 124$ \\
\hline Nûk takisôq Mb & 455835 & $71^{\circ} 05.35^{\prime}$ & $53^{\circ} 54.54^{\prime}$ & Plagioclase & $57.25 \pm 0.95$ & 70.2 & $57.33 \pm 1.35$ & 0.58 & $292 \pm 39$ \\
\hline Qeqertalik Mb & 455877 & $71^{\circ} 03.70^{\prime}$ & $53^{\circ} 50.10^{\prime}$ & Plagioclase & No plateau & 60.0 & $59.50 \pm 1.71$ & 1.60 & $309 \pm 13$ \\
\hline Qeqertalik Mb & 455809 & $71^{\circ} 02.38^{\prime}$ & $53^{\circ} 43.45^{\prime}$ & Plagioclase & $59.97 \pm 0.89$ & 100 & $58.98 \pm 1.88$ & 1.26 & $326 \pm 51$ \\
\hline \multicolumn{10}{|c|}{ Volcanic succession on western Nuussuaq and Hareøen } \\
\hline upper Kanísut Mb & 135152 & $70^{\circ} 43.88^{\prime}$ & $54^{\circ} 26.80^{\prime}$ & Alkali feldspar & $54.03 \pm 0.33$ & 92.0 & $54.14 \pm 0.37$ & 0.48 & $255 \pm 69$ \\
\hline middle Kanísut Mb & 410140 & $70^{\circ} 39.61^{\prime}$ & $54^{\circ} 34.70^{\prime}$ & Sanidine & $54.86 \pm 0.32$ & 93.0 & $54.86 \pm 0.36$ & 0.91 & $295 \pm 15$ \\
\hline lower Kanísut Mb & 456257 & $70^{\circ} 24.70^{\prime}$ & $54^{\circ} 59.69^{\prime}$ & Plagioclase & $56.15 \pm 0.41$ & 100 & $56.15 \pm 0.42$ & 0.06 & $295 \pm 18$ \\
\hline upper Ifsorisok Mb & 489172 & $70^{\circ} 49.72^{\prime}$ & $54^{\circ} 04.15^{\prime}$ & Alkali feldspar & $58.31 \pm 0.30$ & 100 & $58.39 \pm 0.35$ & 0.83 & n.d. \\
\hline middle Ifsorisok $\mathrm{Mb}$ & 489165 & $70^{\circ} 49.72^{\prime}$ & $54^{\circ} 04.15^{\prime}$ & Alkali feldspar & $58.66 \pm 0.34$ & 94.7 & $58.66 \pm 0.37$ & 0.25 & $296 \pm 75$ \\
\hline \multicolumn{10}{|l|}{ Hellefisk-1 well } \\
\hline $2889.5 \mathrm{~m} \mathrm{brt}$ & 02A-00-0431 & $67^{\circ} 52.618^{\prime}$ & $56^{\circ} 44.041^{\prime}$ & Whole-rock & $61.34 \pm 1.16$ & 93.7 & $60.77 \pm 1.63$ & 1.74 & $298 \pm 5$ \\
\hline $2938.3 \mathrm{~m}$ brt & $02 \mathrm{~A}-00-0447$ & $67^{\circ} 52.618^{\prime}$ & $56^{\circ} 44.041^{\prime}$ & Whole-rock & $59.69 \pm 1.33$ & 84.8 & $59.95 \pm 2.00$ & 0.16 & $295 \pm 3$ \\
\hline
\end{tabular}

Six-digit sample numbers are GGU numbers.

Isochron ages and intercept values are from the inverse isochrons. Details are provided in the online Supplementary Material at http://journals.cambridge.org/geo. n.d. - not defined; points cluster.

*The result for the Qaarsut sill sample 402581 is considered unreliable. See text for discussion. 

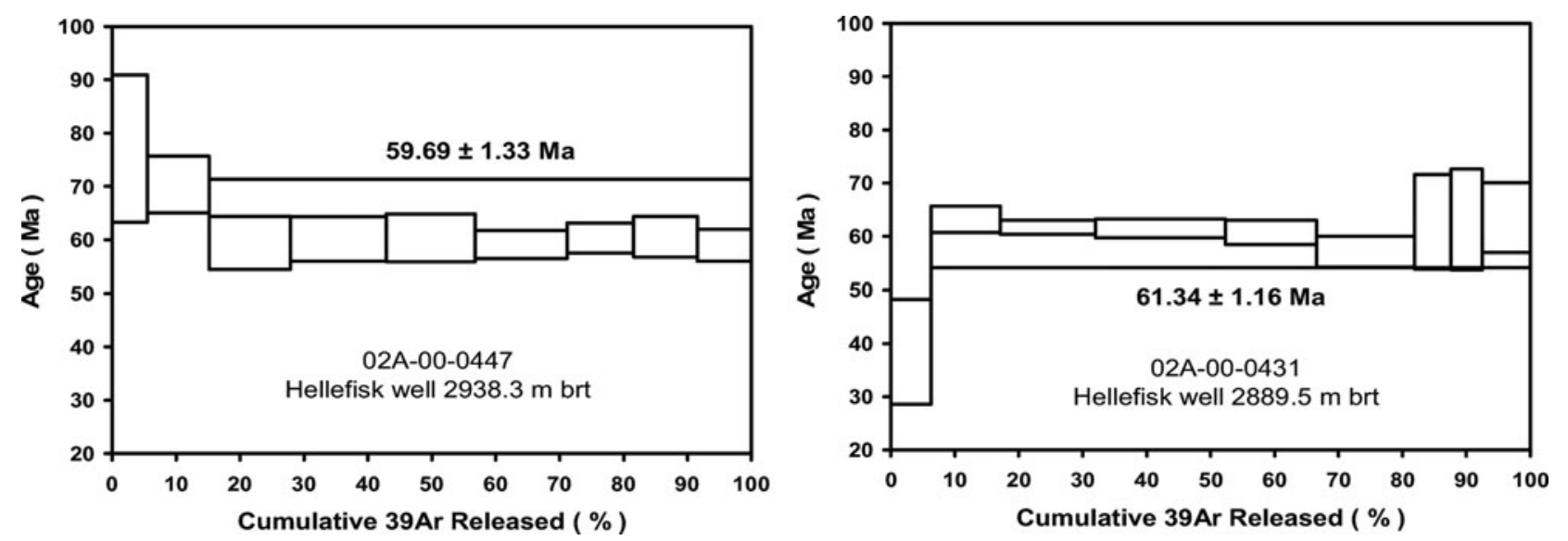

Figure $4 .{ }^{40} \mathrm{Ar}-{ }^{39} \mathrm{Ar}$ age spectra and plateau ages for two samples from the lava succession in the Hellefisk-1 well.

volcanic succession. It is $50 \mathrm{~m}$ thick and compositionally unique, consisting of strongly alkaline olivine-rich picrite containing pegmatitic segregation veins near the top (Drescher, 1933; Clarke \& Pedersen, 1976). It is cut by a fine-grained chilled sheet of alkali basalt. For this study, we selected a pegmatite vein from the Qaarsut sill and a sample of a plagioclase-phyric alkali basalt sill cutting hyaloclastites $700 \mathrm{~m}$ higher up the mountainside $6 \mathrm{~km}$ south of the picrite sill. The alkali basalt sill is chemically very similar to the sheet that cuts the Qaarsut sill; this sheet is altered and unsuitable for ${ }^{40} \mathrm{Ar}-{ }^{39} \mathrm{Ar}$ dating.

\section{5.b.1. Results}

The low-potassium gabbro sill intrusion in Disko Bugt gave a well-constrained plateau age of $58.96 \pm 0.51 \mathrm{Ma}$. Very similar ages were obtained for the low-potassium dyke in eastern Disko: $58.34 \pm 0.40 \mathrm{Ma}$, and that in northern Disko: $57.49 \pm 1.40 \mathrm{Ma}$ (Fig. 5). The age plateau in the latter result comprises only $22 \%$ of the released ${ }^{39} \mathrm{Ar}$ but is consistent with the two better determined dyke ages.

The Qaarsut sill pegmatite gave a precise age of $51.63 \pm 0.29 \mathrm{Ma}$ (shown in the online Supplement-

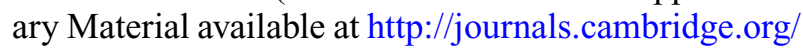
geo). The nearby alkali basalt sill gave a plateau age of $54.52 \pm 0.67 \mathrm{Ma}$ (Fig. 5), despite the fact that the Qaarsut sill is cut by an alkali basalt sheet with a composition very nearly identical to the basalt sill dated here. Unless nearly identical magmas were generated and intruded in the same area at least $2.8 \mathrm{Ma}$ apart, then one of the two age results is wrong. We suspect the age of the pegmatite is too young because other alkaline activity is known from the province $c$. 55-53 Ma but not c. 52-51 Ma; however, this is conjectural.

\section{5.c. Hareøen and Nuussuaq west of the Itilli Fault}

The stratigraphy in this heavily faulted area was established by Hald (1976). The lowest basaltic rocks are low-potassium basalts of the Nûluk Member. On Nuus- suaq, this is overlain by the Ifsorisok Member, which comprises a c. $200 \mathrm{~m}$ thick coarse basaltic mass-flow (talus?) deposit overlain by c. $30 \mathrm{~m}$ of acid tuffs and tuffaceous mudstones with coal. This is overlain by more than $2 \mathrm{~km}$ of lava flows of the Kanísut Member. These flows are enriched tholeiitic basalts very similar to the basalts of the Naqerloq Formation on Svartenhuk Halvø (see Section 5.e below). The Kanísut Member also includes acid tuffs at low, intermediate and high levels in the succession. The age results indicate that the Ifsorisok Member should be placed in the Svartenhuk Formation and the Kanísut Member in the Naqerloq Formation (Fig. 3); the position of the Nûluk Member remains uncertain.

The Hareøen Formation is present only on Hareøen where it overlies the Naqerloq Formation unconformably (Hald \& Pedersen, 1975). It is composed of a lower sedimentary member of sandstones and mudstones with coal (the Aumarûtigssâ Member, Fig. 3) and an upper volcanic member, the c. $300 \mathrm{~m}$ thick Talerua Member, of transitionally alkaline basalts which are not cut by any dykes.

For this study, we selected a stratigraphic suite of two tuffs from the Ifsorisok Member, three tuffs from the Kanísut Member, and one lava from the Talerua Member. Two tholeiitic basalt dykes cutting the upper part of the Kanísut Member on Nuussuaq were included to represent the latest igneous activity in western Nuussuaq. No samples from the Nûluk Member were suitable for ${ }^{40} \mathrm{Ar}-{ }^{39} \mathrm{Ar}$ dating.

\section{5.c.1. Results}

The two tuff samples from the Ifsorisok Member both gave precise ages of $58.66 \pm 0.34 \mathrm{Ma}$ and $58.31 \pm 0.30 \mathrm{Ma}$, in correct stratigraphic order (Fig. 6).

The three tuffs from the lower, middle and upper part of the Kanísut Member all gave precise ages of, respectively, $56.15 \pm 0.41 \mathrm{Ma}, 54.86 \pm 0.32 \mathrm{Ma}$ and $54.03 \pm 0.33 \mathrm{Ma}$, in accord with the stratigraphy. Storey et al. (1998) obtained an age of $53.2 \pm 0.4 \mathrm{Ma}$ for a tuff from the middle part of the Kanísut Member; however, that age spectrum is discordant, with 

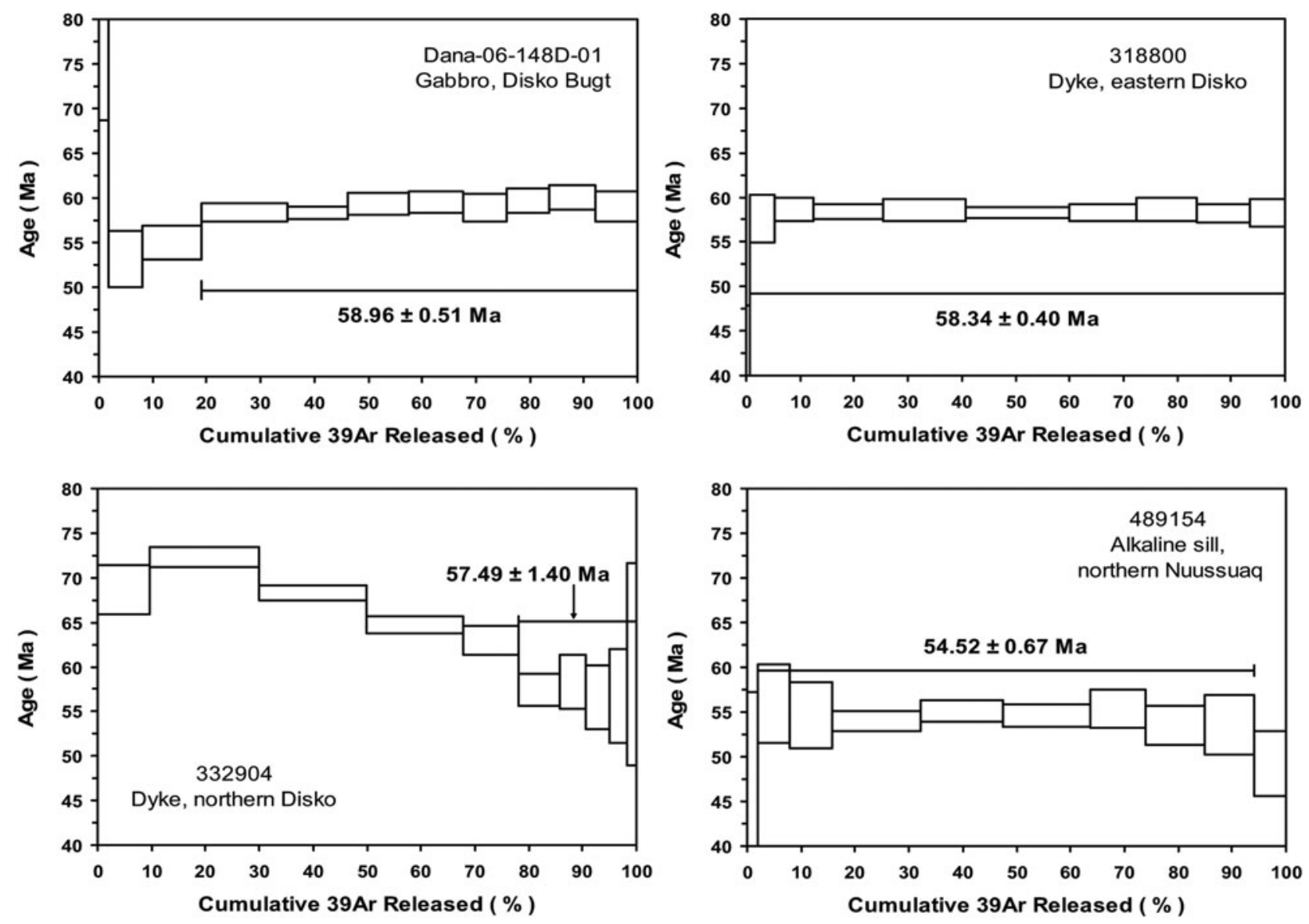

Figure 5. ${ }^{40} \mathrm{Ar}-{ }^{39} \mathrm{Ar}$ age spectra and plateau ages for intrusive rocks from Disko Bugt, Disko and Nuussuaq east of the Itilli Fault.

alternating older and younger step ages that produce a very large mean square weighted deviation (MSWD) (not reported). This earlier age is superseded by our new results.

A late dyke in westernmost Nuussuaq gave an imprecise age of $48.02 \pm 2.76 \mathrm{Ma}$ (Fig. 6). A second dyke produced an Ar recoil pattern and no certain age information.

A lava flow from the Hareøen Formation has been dated twice, in 2004 and 2013 (Fig. 6). The results are in complete agreement: $38.57 \pm 0.24 \mathrm{Ma}$ in 2004 and $38.90 \pm 0.23 \mathrm{Ma}$ in 2013, demonstrating excellent repeatability of analyses in the laboratory over a tenyear period.

\section{5.d. Ubekendt Ejland}

The major part of Ubekendt Ejland consists of a uniform succession of picrite lavas of the Vaigat Formation. Owing to faulting and the lack of marker horizons the thickness of a maximum of $5 \mathrm{~km}$ estimated by Larsen (1977b) is uncertain. The picrite lavas are correlated with the Nunavik Member on Svartenhuk Halvø and the Ordlingassoq Member on Nuussuaq and Disko (Fig. 3).

The stratigraphy of the basalts overlying the Vaigat Formation was established by Larsen $(1977 a)$ for the geological map (scale 1:100 000) Igdlorssuit 71 V.1 Syd
(Larsen, 1983). The basalt succession is up to $5 \mathrm{~km}$ thick and originally three members were referred to the Maligât Formation. However, only the up to $3500 \mathrm{~m}$ thick lower member (Qeqertalik Member) is dominated by tholeiitic low-potassium basalts. The overlying $750 \mathrm{~m}$ thick Tuperssuartâta kûa Member consists of tuffs and pitchstones with a few alkali basaltic lava flows, and the 400-700 m thick upper member (Nûk takisôq Member) is dominated by alkaline and enriched tholeiitic basalts with acid tuff layers (Larsen, 1977a). In accord with both compositions and ages, we have placed the Qeqertalik Member in the Svartenhuk Formation and the Nûk takisôq Member in the Naqerloq Formation (Fig. 3). The Tuperssuartâta kûa Member is undated and is tentatively retained in the Svartenhuk Formation because it is bounded upwards by an angular unconformity (Larsen, 1977a). The uppermost $150 \mathrm{~m}$ of the lava succession consists of alkali basalts and is referred to the Erqua Formation (Larsen, 1977a). The Erqua Formation is present only in a $3.5 \mathrm{~km}$ long coastal strip in westernmost Ubekendt Ejland.

Ubekendt Ejland houses the only major onshore central intrusive complex in the Nuussuaq Basin, the Sarqâta qáqâ complex, which is emplaced into the picrites of the Vaigat Formation (Drever \& Game, 1948; Drever, 1958). It is a gabbro-granophyre complex with an ovoid-elongate shape 5.5 by $2 \mathrm{~km}$ in size. 

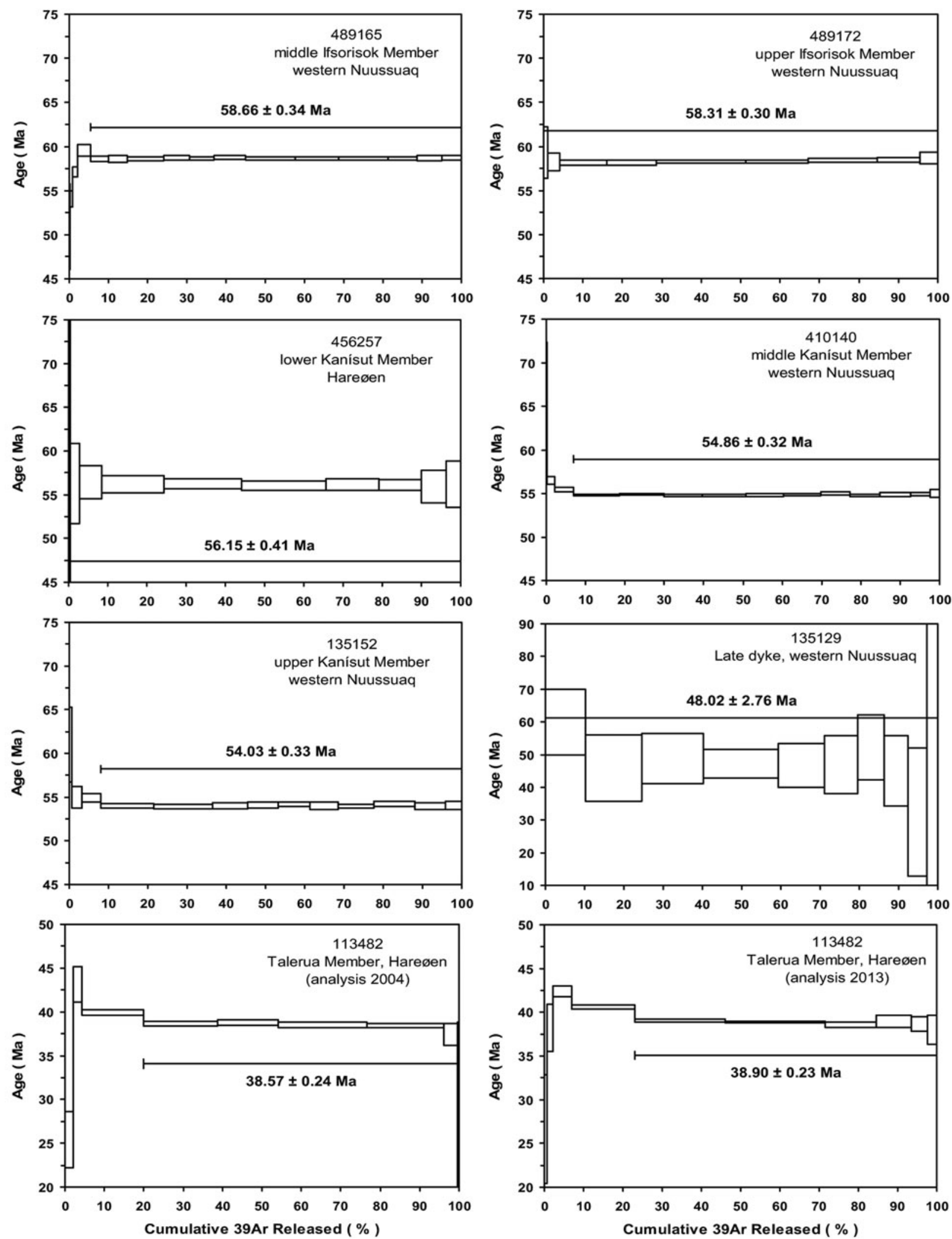

Figure 6. ${ }^{40} \mathrm{Ar}-{ }^{39} \mathrm{Ar}$ age spectra and plateau ages for extrusive rocks and a dyke from Hareøen and Nuussuaq west of the Itilli Fault.

The upper part of the volcanic succession on the west coast of Ubekendt Ejland is cut by a NNW-trending swarm of alkaline lamprophyre dykes (Drever \& Game, 1948; Larsen, 1981; Clarke, Muecke \& Pe-Piper, 1983). These were ${ }^{40} \mathrm{Ar}-{ }^{39} \mathrm{Ar}$ dated by Parrott \& Reynolds
(1975) to 30-39 Ma and by Storey et al. (1998) to $34.5 \pm 0.4 \mathrm{Ma}$.

For this study, we selected a stratigraphic sample suite consisting of ten lava samples from the Svartenhuk, Naqerloq and Erqua formations, as well as two 
samples from the Sarqâta qáqâ complex, a gabbro and a granophyre.

\section{5.d.1. Results}

The samples from this area have been the most difficult to date. Five out of 12 samples failed to yield any useful age information. Seven samples gave good plateau ages in reasonable accord with the stratigraphy (Fig. 7). In stratigraphic order, the Qeqertalik Member gave ages of $59.97 \pm 0.89 \mathrm{Ma}$ and $59.50 \pm 1.71 \mathrm{Ma}$; the lower Nûk takisôq Member gave $57.25 \pm 0.95 \mathrm{Ma}$ and a pitchstone from the middle Nûk takisôq Member gave $55.94 \pm 0.20 \mathrm{Ma}$; the Erqua Formation gave $53.47 \pm 0.52 \mathrm{Ma}$, distinctly younger than the underlying lavas. The Tuperssuartâta kûa Member and the upper Nûk takisôq Member (Fig. 3) remain undated.

For the Sarqâta qáqâ complex, the gabbro gave $56.99 \pm 0.49 \mathrm{Ma}$ and the granophyre gave $55.21 \pm 0.30 \mathrm{Ma}$; the two ages are outside the uncertainty of each other. Beckinsale, Thompson \& Durham (1974) dated biotite from two gabbro samples by the $\mathrm{K}-\mathrm{Ar}$ method to $55.4 \pm 1.5 \mathrm{Ma}$ and $54.0 \pm 1.5 \mathrm{Ma}$, in agreement with our results. They also constructed a $\mathrm{Rb}-\mathrm{Sr}$ whole-rock isochron for both gabbro and granophyre samples resulting in an age of $65 \pm 5 \mathrm{Ma}$. They concluded that the intrusion had a very long cooling time, but in the light of the new results this conclusion cannot be upheld, although the gabbro still appears to be somewhat older than the granophyre.

\section{5.e. Svartenhuk Halvo and further north}

The volcanic stratigraphy of this area is shown in the geological map (scale 1:100 000) Svartenhuk 71 V.1 Nord (Larsen \& Grocott, 1991). It was also described in part by Larsen \& Pulvertaft (2000). The exposed part of the Vaigat Formation is up to more than $2.5 \mathrm{~km}$ thick and the major part of it (the Nunavik Member) is thought to correlate with the Ordlingassoq Member on Disko and Nuussuaq. The small, crustally contaminated Kakilisaat Member may perhaps correspond to the uppermost part of the Naujánguit Member (Fig. 3).

In northern Svartenhuk Halvø and further north, an up to $110 \mathrm{~m}$ thick sedimentary succession of sandstones and mudstones with coal layers separates the Vaigat Formation from the basalt lavas of the Svartenhuk Formation. As originally defined, the Svartenhuk Formation has a combined volcanic thickness of $c$. $2800 \mathrm{~m}$, but because of abrupt changes of both composition and age the uppermost part $(c .800 \mathrm{~m})$ is here moved to the new Naqerloq Formation (Fig. 3). The boundary between the Svartenhuk and Naqerloq formations was not given special attention during field work; the horizon is very poorly exposed, which could suggest the existence of sediments at that level.

The Naqerloq Formation is only preserved in western Svartenhuk Halvø where strong faulting and poor exposure has encumbered the establishment of an internal stratigraphy for the formation. In particular, the position of a unique porphyritic trachyte lava flow (the Arfertuarsuk flow) is uncertain.

For this study, we selected a stratigraphic sample suite consisting of two samples from the Vaigat Formation and seven samples from the overlying basalt succession.

\section{5.e.1. Results}

The two samples from the Vaigat Formation both showed Ar recoil problems and failed to yield any reliable age information. The succession is reversely magnetized like the middle and upper part of the Vaigat Formation on Disko and Nuussuaq (Riisager, Riisager \& Perrin, 1999; Riisager, Riisager \& Pedersen, 2003) and is most probably contemporaneous with this.

The samples from the basalt succession overlying the Vaigat Formation gave good age results (Fig. 8). For the Svartenhuk Formation, the ages are in accord with the stratigraphy: two samples from the lower part of the Tunuarsuk Member gave plateau ages of $60.31 \pm 1.39 \mathrm{Ma}$ and $59.41 \pm 0.61 \mathrm{Ma}$, the Nuuit Member gave $58.05 \pm 0.59 \mathrm{Ma}$, and the Skalø Member gave $57.98 \pm 0.59 \mathrm{Ma}$.

The Arfertuarsuk trachyte flow has been considered to be part of the Eocene succession, based on field work. However, the age of its abundant centimetre-sized anorthoclase crystals is Paleocene, $57.51 \pm 0.24 \mathrm{Ma}$. Either this age is not the extrusion age of the flow or the flow has been misplaced in the strongly faulted stratigraphy; dating of the groundmass feldspar is pending.

Two samples from the Naqerloq Formation gave plateau ages of $55.91 \pm 0.60 \mathrm{Ma}$ and $54.86 \pm 0.44 \mathrm{Ma}$, results just within $2 \sigma$ of each other. The samples are situated $40 \mathrm{~km}$ apart and their relative place in the stratigraphy is not certain.

Parrott \& Reynolds (1975) provided the first radiometric ages for the basalts on Svartenhuk Halvø in the form of three ${ }^{40} \mathrm{Ar}-{ }^{39} \mathrm{Ar}$ isochron ages ranging from $57.9 \pm 1.0 \mathrm{Ma}$ to $59.4 \pm 2.6 \mathrm{Ma}$ and one age of $51.4 \pm 11.0 \mathrm{Ma}$. There is no information on which part of the succession the samples come from, but the ages are similar to our results for the Nuuit and Skalø members.

\section{Age of igneous rocks along the West Greenland margin south of the Nuussuaq Basin}

Except for the Hellefisk-1 well, Tertiary igneous rocks south of the Nuussuaq Basin (Fig. 1) are sampled only from dykes in the onshore areas and by dredging in the offshore areas (Fig. 9). A sill and a dyke in the Aasiaat region dated by Larsen et al. (2009) belong to the southernmost extension of the Nuussuaq Basin and will be discussed in Sections 7.b and 7.e below. A basalt dyke at $66^{\circ} 27^{\prime} \mathrm{N}$ near Itilleq (sampled during reconnaissance because 'it looked Tertiary') has an age of $64.0 \pm 1.3 \mathrm{Ma}$ (Larsen et al. 2009). Small alkali basaltic dykes (camptonitic lamprophyres) at 

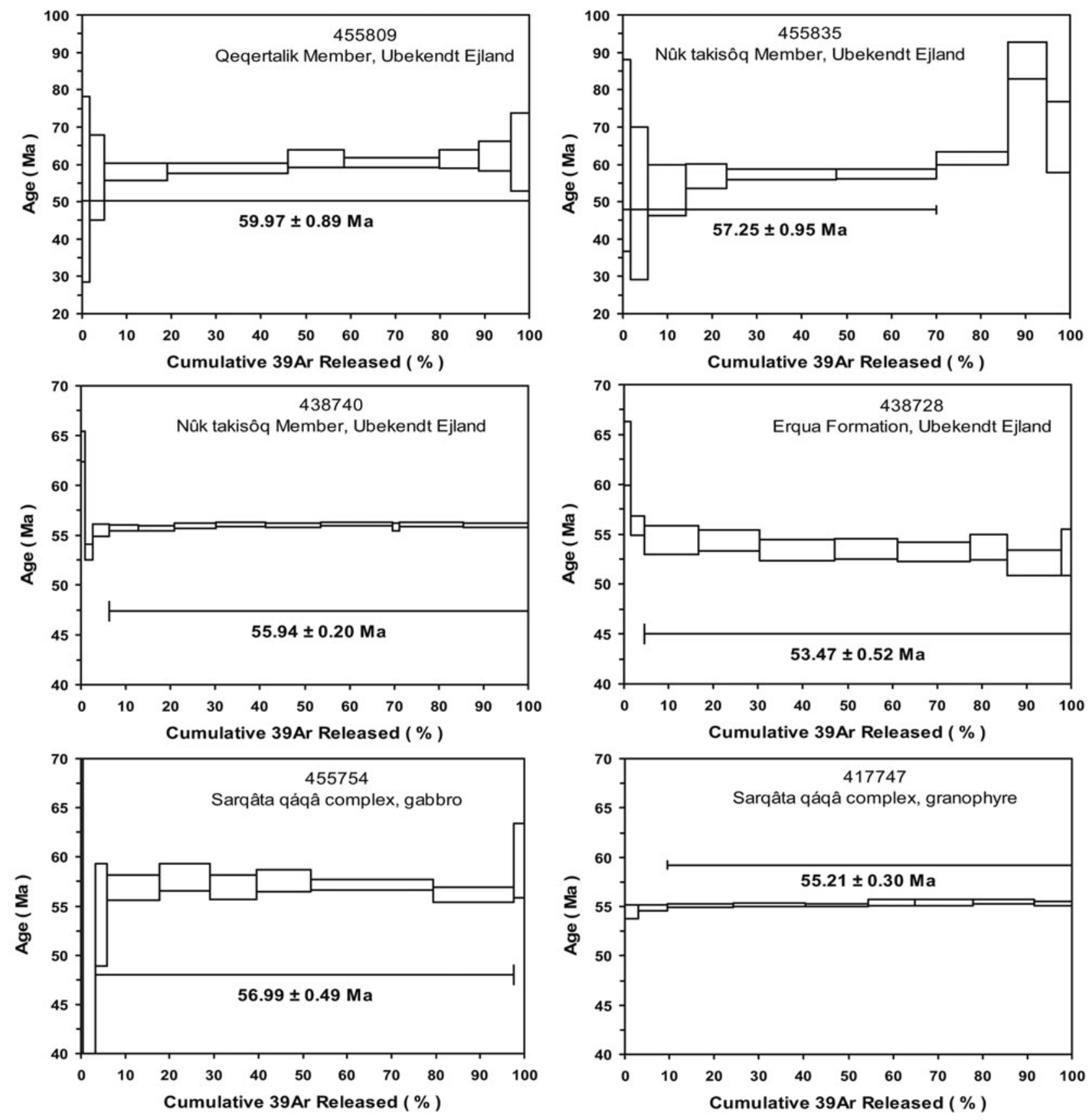

Figure 7. ${ }^{40} \mathrm{Ar}-{ }^{39} \mathrm{Ar}$ age spectra and plateau ages for extrusive and intrusive rocks from Ubekendt Ejland. Diagrams for a sample giving an isochron age but no plateau age (455877) are found in the online Supplementary Material available at http://journals.cambridge.org/geo.

$65^{\circ} 23-30^{\prime} \mathrm{N}$ around Søndre Isortoq form a local swarm and are dated at $58.4 \pm 0.6 \mathrm{Ma}, 55.8 \pm 0.6 \mathrm{Ma}$ and $55.2 \pm 1.2 \mathrm{Ma}$; another similar small swarm occurs in the Godthåbsfjord area around $64^{\circ} \mathrm{N}$ and is dated at $51.8 \pm 0.9 \mathrm{Ma}$ (Larsen et al. 1999, 2009; Larsen, 2006).

Dredging around $66^{\circ} 30^{\prime} \mathrm{N}$ on the northern Davis Strait High and south of $63^{\circ} 30^{\prime} \mathrm{N}$ along the walls of a submarine canyon and on a number of seamounts produced a large number of volcanic samples besides obviously ice-rafted material (Dalhoff et al. 2006; Larsen \& Dalhoff, 2006, 2007). All the igneous rocks dredged from the Davis Strait High are geochemically unique and considered to be local; one sample gave an age of $63.4 \pm 0.7 \mathrm{Ma}$ as discussed in the next section.
For rocks dredged south of $63^{\circ} 30^{\prime} \mathrm{N},{ }^{40} \mathrm{Ar}-{ }^{39} \mathrm{Ar}$ dating revealed ten Tertiary igneous rocks (Larsen \& Dalhoff, 2006, 2007) (Fig. 9). The oldest sample is a rhyolite with a Paleocene age of $59.3 \pm 0.4 \mathrm{Ma}$; it is geochemically distinct from all the analysed rhyolites in the Nuussuaq Basin (Larsen \& Pedersen, 2009 and unpub. data). Five samples cluster in the interval 56.5-54 Ma and four samples have younger ages of 52.8-48.4 Ma. The by far most frequently found geochemical type south of $63^{\circ} 30^{\prime} \mathrm{N}$ (the 'main basalts' of Larsen \& Dalhoff, 2006, 2007) includes both age groups. The 'main basalts' are both chemically and agewise quite similar to the enriched tholeiites of the Naqerloq Formation in the Nuussuaq Basin. As the 

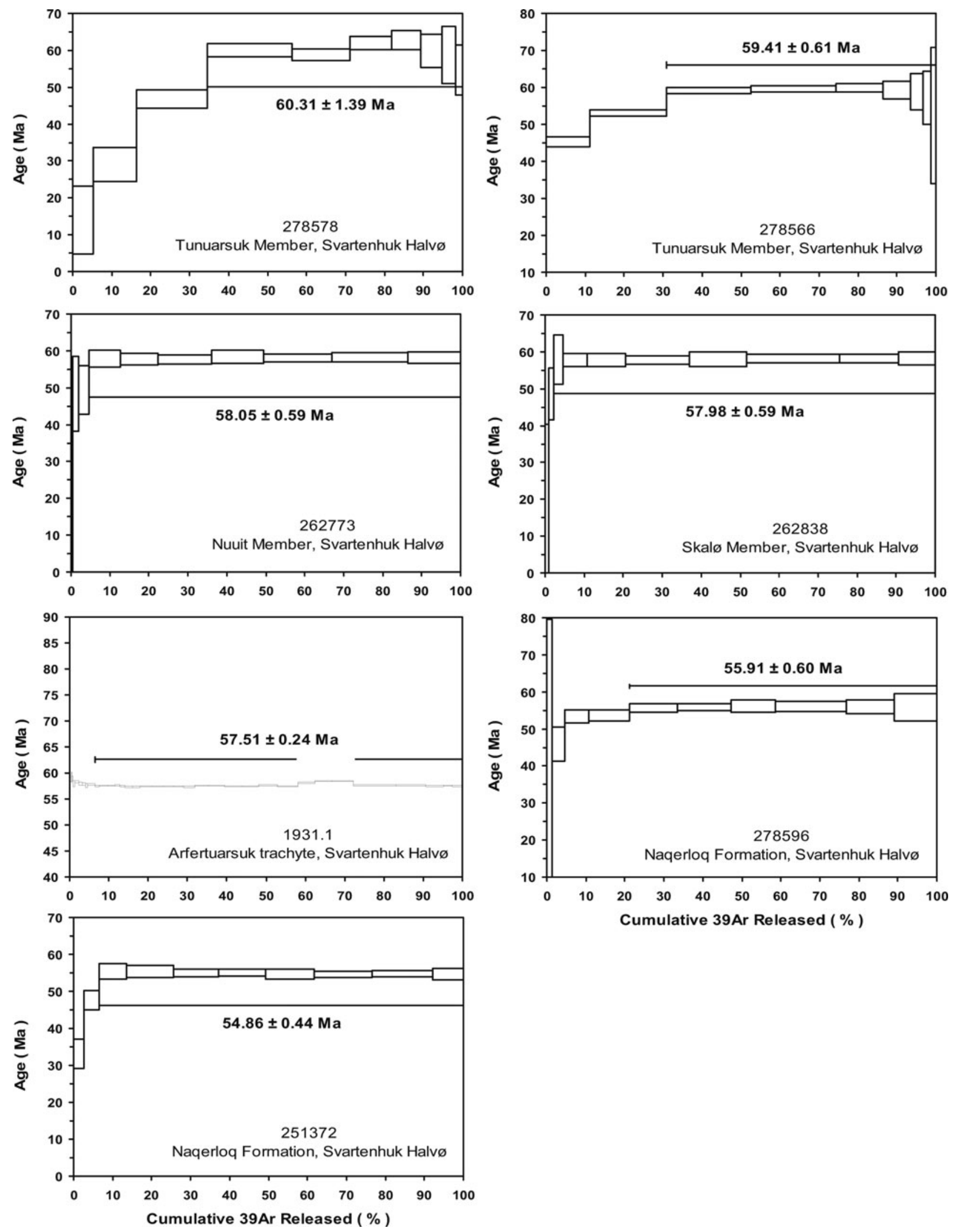

Figure $8 .{ }^{40} \mathrm{Ar}-{ }^{39} \mathrm{Ar}$ age spectra and plateau ages for lavas from Svartenhuk Halvø.

rocks are ice-transported, their place of origin is debatable. Larsen \& Dalhoff $(2006,2007)$ discussed the possible origins and concluded that a source in the nearby Hecla High volcanic centre at $64^{\circ} \mathrm{N}$ (Fig. 1) is the most likely. The lava succession here is dated stratigraphically as Eocene and possibly older, and seismic sections show that an eroded and tilted cuesta landscape of lava flows has been exposed subaerially until some time during the Pleistocene (Sørensen, 2006; Larsen \& Dalhoff, 2006). A local ice cap on the 


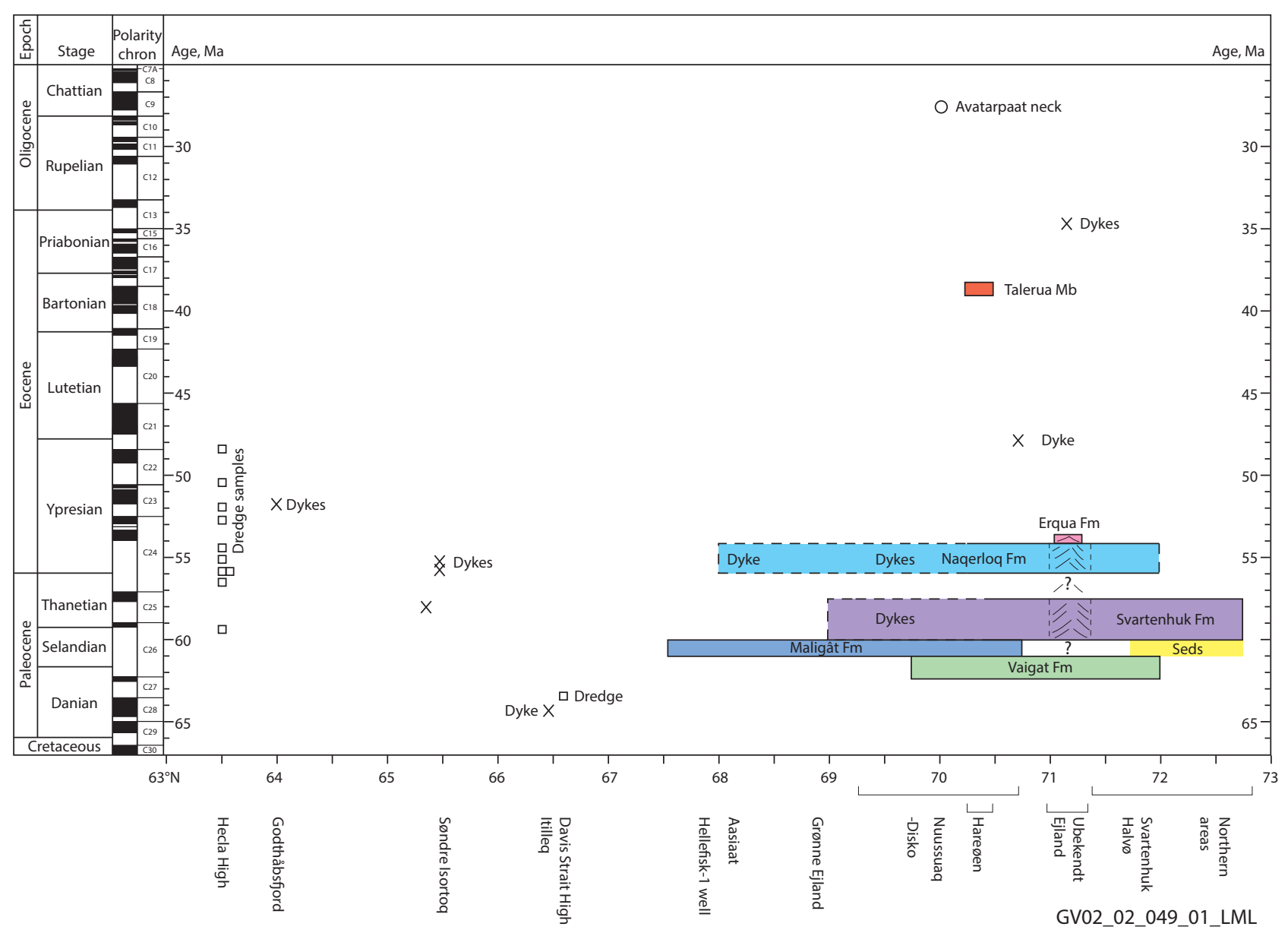

Figure 9. Extent and ages of Tertiary igneous rocks along the West Greenland margin at $63-73^{\circ} \mathrm{N}$, plotted according to geographical latitude. The dredge samples in the southern area are all shown at $63^{\circ} 30^{\prime} \mathrm{N}$; the dredge positions varied from $62^{\circ} 28^{\prime} \mathrm{N}$ to $63^{\circ} 30^{\prime} \mathrm{N}$. Data are given in the online Supplementary Material available at http://journals.cambridge.org/geo. Stages and magnetic polarity chrons after the Geologic Time Scale 2012. Colours refer to Figure 3; the line pattern for Ubekendt Ejland suggests a central volcano.

Hecla High could have dispersed lava material into the surroundings.

The volcanic succession on the Maniitsoq High is unsampled, whereas the succession in the Nukik area (Fig. 1) is drilled but not radiometrically dated. The Nukik-2 well comprises in its lowest part a thick succession of low-potassium (intrusive?) dolerites assumed to be Paleocene and a few higher volcaniclastic horizons embedded in upper Paleocene sediments (Hald \& Larsen, 1987; Nøhr-Hansen, 2003). The Gjoa Rise is drilled by the well Gjoa G-37, and two basalt samples gave Paleocene ages of $c$. $60 \mathrm{Ma}$ (Williamson et al. 2001).

\section{Volcanic development of the West Greenland margin}

7.a. Late Danian to Selandian, 64-61 Ma: Vaigat Formation and other picritic and basaltic volcanism

The picritic Vaigat Formation forms a N-S-elongated shield-like deposit extending from Disko to just north of Svartenhuk Halvø (Fig. 2), with a maximum thickness around Ubekendt Ejland and petering out both to the south and to the north. It also peters out east- wards where it overlies sediments and high basement. There are many local eruption sites and the lava flows did not travel far (Pedersen et al. 2002). The oldest exposed part is the Anaanaa Member, which is found only in a small area in western Nuussuaq immediately east of the Itilli Fault. From there, the eruption sites moved gradually eastwards, filling in the basin with hyaloclastites and subaerial lava flows (Pedersen, Larsen \& Dueholm, 1993, 2002; Larsen \& Pedersen, 2009). Whereas the Anaanaa Member is normally magnetized, the major (middle and upper) part of the Vaigat Formation is reversely magnetized, and the $61.1 \pm 2.0 \mathrm{Ma}$ to $61.5 \pm 1.0 \mathrm{Ma}$ ages for this part obtained by Storey et al. (1998) place its eruption within magnetic polarity chron C26r (62.2-59.2 Ma) and the eruption of the Anaanaa Member therefore in C27n (62.5-62.2 Ma) (Riisager \& Abrahamsen, 1999) (Fig. 9). The Vaigat Formation may extend well offshore (see Section 8.a below).

Similar picritic volcanic rocks are found at Cape Dyer on Baffin Island (Clarke \& Upton, 1971). The lavas there are normally magnetized (Deutsch, Kristjansson \& May, 1971) and are most probably contemporaneous with the Anaanaa Member (Pedersen et al. 2002); they are only slightly different in 
chemistry (Starkey et al. 2009). Clarke \& Upton (1971) reported a $\mathrm{K}-\mathrm{Ar}$ age of $58 \pm 2 \mathrm{Ma}$ but otherwise the rocks have not been radiometrically dated. Areas with volcanic rocks also extend seawards of Cape Dyer (MacLean, Falconer \& Clarke, 1978; Skaarup, Jackson \& Oakey, 2006); drilled rocks described by MacLean, Falconer \& Clarke (1978) are vesicular, apparently subaerial, olivine-phyric (picritic?) nearest Cape Dyer and plagioclase-phyric (basaltic?) further south.

A plate reconstruction for magnetic polarity chron C27n time (62.5-62.2 Ma) shows Cape Dyer and northern Disko situated just opposite each other with $180 \mathrm{~km}$ between them (Skaarup, Jackson \& Oakey, 2006; Oakey \& Chalmers, 2012), less than the $260 \mathrm{~km}$ $\mathrm{N}-\mathrm{S}$ extension of the Vaigat Formation. It is likely that picrite volcanism extended over the whole basinal area between the two margins, particularly if the stretched lithosphere was thinnest in the centre of the basin, facilitating high degrees of mantle melting. Eruption sites would have been local but the volcanic products, consisting mainly of marine hyaloclastites, could have merged into a coherent deposit.

Picrites were also erupted on or along the Davis Strait High c. $300 \mathrm{~km}$ south of Disko. Picritic vesicular lava blocks, interpreted to be of local origin, have been dredged on the northern Davis Strait High around $66^{\circ} 30^{\prime} \mathrm{N}$, indicating that parts of the high reached above sea level (Larsen \& Dalhoff, 2006). The rocks have low-potassium, chemically depleted compositions closely akin to the picrites on Baffin Island and in Greenland but show evidence of higher degrees of melting beneath a thinner lithospheric lid than on either side. One basalt sample was dated at $63.35 \pm 0.74 \mathrm{Ma}$ (Larsen \& Dalhoff, 2006). This volcanism may have been sourced in the developing 'leaky transform' Ungava fault zone with its associated thick igneous crust on the western side of the Davis Strait High (Funck et al. 2012).

Further south, in the Labrador Sea, Keen, Dickie \& Dehler (2012) interpreted a period of excess volcanism in $\mathrm{C} 27 \mathrm{n}$ time, giving rise to extensive volcanic highs along both margins, formed before normal seafloor spreading began. The oldest Tertiary radiometric age obtained in West Greenland is from the basalt dyke near Itilleq at $66^{\circ} 27^{\prime} \mathrm{N}$, nearly the same latitude as the dredges on the Davis Strait High (Fig. 1). The dyke strikes N-S, i.e. coast-parallel, and has a low-potassium geochemical character; its age of $64.0 \pm 1.3 \mathrm{Ma}$ (Larsen et al. 2009) is similar within the analytical uncertainty to the age of the sample from the Davis Strait High. This suggests that magma production took place even earlier than $\mathrm{C} 27 \mathrm{n}$ and that such early volcanic rocks may be more widespread than previously thought.

\section{7.b. Selandian, 61-60 Ma: Maligât Formation and offshore basaltic volcanism}

The demise of the Vaigat Formation must have involved establishment of deep crustal magma cham- bers where the picritic magmas stalled and differentiated into basalt (Larsen \& Pedersen, 2009). The earliest of the basalt formations, the Maligât Formation $(61.3 \pm 0.8 \mathrm{Ma}$ to $60.2 \pm 1.0 \mathrm{Ma}$; Storey et al. 1998), is reversely magnetized and was erupted within magnetic polarity chron C26r (62.2-59.2 Ma) (Riisager \& Abrahamsen, 1999). The formation is centred on Disko just south of the dome of the Vaigat Formation and is thickest and comprises the largest number of lava flows in western Disko (e.g. Pedersen et al. 2003, 2005). The Maligât Formation is therefore considered to continue westwards on the shelf as part of the large lava plateau there (Fig. 1).

Activity within the lava plateau at this time extended south to the areas around $67^{\circ} 30^{\prime} \mathrm{N}$ where the basalt succession in the Hellefisk-1 well $(60.63 \pm 0.87 \mathrm{Ma})$ was formed at the same time. A basalt sill intruding Cretaceous sediments on Grønne Ejland in the southeastern part of Disko Bugt (Fig. 2) with low-potassium geochemistry has an age of $60.81 \pm 0.88 \mathrm{Ma}$ (Larsen et al. 2009) and is also part of this activity.

The Maligât Formation spread northwards on northern Disko and Nuussuaq but only the stratigraphically highest parts reached northern Nuussuaq, and the formation probably never extended north of Nuussuaq. Further north this period was a time of volcanic quiescence and erosion, leading to deposition of quartzofeldspathic sediments and reworked volcaniclastic material in northern Svartenhuk Halvø and north of it (Fig. 9).

\section{7.c. Late Selandian to Thanetian, 60-58 Ma: Svartenhuk Formation basaltic volcanism, tuffs and dykes}

The earliest lavas of the Svartenhuk Formation, the Tunuarsuk Member, were erupted on Svartenhuk Halvø where the lowest lavas interdigitate with quartzofeldspathic and volcaniclastic sediments (Fig. 3). There does not seem to be much age difference, if any, from the latest member of the Maligât Formation; all are dated at c. $60 \mathrm{Ma}$ and they may be essentially contemporaneous but originated in different volcanic systems. The overlying Nuuit and Skalø members with ages of $c$. $58 \mathrm{Ma}$ are definitely younger than the Maligât Formation. All three members are widespread on Svartenhuk Halvø and north of it and there is no indication of thinning towards the coast; it is therefore most likely that the Svartenhuk Formation continues in the offshore lava plateau (see Section 8.a below).

The two presently dated dykes on Disko and the gabbro sill in Disko Bugt have ages of c. 59-58 Ma (Table 1). With both ages and chemical compositions identical to those of the Svartenhuk Formation, this strongly suggests that lavas of the Svartenhuk Formation were present on Disko and Nuussuaq but have now been removed by erosion.

Ubekendt Ejland evolved independently. The lowest basaltic member, the Qeqertalik Member (Fig. 3), was erupted c. $60 \mathrm{Ma}$ and may be partly contemporaneous with the upper Maligât Formation and the Tunuarsuk 
Member, but it is compositionally much more variable and does not correspond to any of the neighbouring successions (Larsen, 1977a and unpub. GEUS data). This makes the occurrence of typical Svartenhuk Formation compositions in dykes and sills further south even more remarkable and prompts the suggestion that a local central volcanic complex had already developed on Ubekendt Ejland at this time. The overlying two members with alkaline lavas and acid tuffs point in the same direction.

The evolution was different again on Nuussuaq west of the Itilli Fault. The undated Nûluk Member is believed to be $c$. $60 \mathrm{Ma}$; the overlying $c$. $200 \mathrm{~m}$ thick basaltic mass-flow deposit of the Ifsorisok Member demonstrates considerable tectonic movements and erosion before $58.6 \pm 0.5 \mathrm{Ma}$, which is the age of the lowest tuff layer overlying the mass-flow. The $30 \mathrm{~m}$ thick tuffs and sediments are contemporaneous with the monotonous tholeiitic lava flows of the Nuuit and Skalø members on Svartenhuk Halvø and the dykes on Disko, illustrating the lateral variability of the volcanic products at that time.

The Nûluk Member is reversely magnetized (Riisager, Riisager \& Pedersen, 2003). The palaeomagnetic directions of the Ifsorisok Member deposits and the lava successions of the Svartenhuk Formation are unknown. The short magnetic polarity chron C26n (59.2$59.0 \mathrm{Ma}$ ) is probably concealed in the interval represented by the Ifsorisok Member mass-flow, but it should be present in the upper part of the Tunuarsuk Member (compare Figs 3 and 9).

In the southern area, the single rhyolite sample dredged at $63^{\circ} 30^{\prime} \mathrm{N}$ and dated at $59.3 \pm 0.4 \mathrm{Ma}$ (Larsen \& Dalhoff, 2006), and considered to originate in the Hecla High volcanic centre (see Section 6 above), suggests the development of a central volcano in the Hecla High area already at this time.

\section{7.d. Latest Thanetian, 58-56 Ma: volcanic near-quiescence and tectonism}

Between Paleocene (Thanetian) and Eocene (Ypresian) time, there was a period of near-quiescence at 58$56 \mathrm{Ma}$ or shorter. The Arfertuarsuk trachyte flow, the only flow of its kind, appears to be produced within this interval, perhaps by prolonged differentiation in a stagnant magma chamber. Where exposures allow observations, the Paleocene volcanic succession is unconformably overlain by the Eocene succession, suggesting tectonic movements; however the horizon is often poorly exposed and is not well investigated.

\section{7.e. Earliest Ypresian, 56-54 Ma: Naqerloq Formation basaltic and rhyolitic volcanism, dykes, sills and central intrusion}

When the volcanism picked up again in Eocene time the basaltic magmas had changed composition from the low-potassium, geochemically depleted basalts characteristic of Paleocene time, to enriched tholeiitic basalts with significantly higher contents of incompatible elements including potassium (Hald, 1976; Larsen, 1977a; Holm, Hald \& Nielsen, 1992; Fig. 10).

Enriched basalts and subordinate acid tuffs of the Naqerloq Formation with ages in the 56-54 Ma interval form thick lava piles in western Nuussuaq and Hareøen (Kanísut Member), western Ubekendt Ejland (Nûk takisôq Member) and western Svartenhuk Halvø. The Naqerloq Formation most likely continues in the offshore areas (see Section 8.a below).

Basaltic dykes of similar enriched composition and age occur throughout Disko and Nuussuaq, and the magmas also intruded as thick sills and sheets along the Eastern Boundary Fault towards the gneiss highlands in eastern Nuussuaq (Larsen et al. 2009). Storey et al. (1998) dated two such dykes to $55.5 \pm 0.8 \mathrm{Ma}$ and $54.3 \pm 0.6 \mathrm{Ma}$, and Larsen et al. (2009) dated a sill along the Eastern Boundary Fault to $56.81 \pm 0.84 \mathrm{Ma}$; all have compositions similar to the Naqerloq Formation. In the Aasiaat district just south of Disko Bugt a $60 \mathrm{~km}$ long, N-S-oriented dyke with similar composition has an age of 56.09 $\pm 0.24 \mathrm{Ma}$ (Larsen et al. 2009). From the south coast of Svartenhuk Halvø, Geoffroy et al. (2001) K-Ar dated two sets of dykes cutting the Vaigat Formation to $54.7 \pm 1.3 \mathrm{Ma}$ and $55.1 \pm 2.3 \mathrm{Ma}$. There is thus substantial evidence that the Naqerloq Formation originally extended well beyond its present limits and into the southern and eastern part of the Nuussuaq Basin.

Whereas the Naqerloq Formation basalts on western Nuussuaq, Hareøen and Svartenhuk Halvø are closely similar geochemically, the succession on Ubekendt Ejland is different and more variable (Larsen, 1977a and unpub. GEUS data). It contains more acid pitchstones and tuffs and some alkaline lavas, suggesting that a central volcanic complex with an underlying magma chamber was well developed at this time. The 5755 Ma Sarqâta qáqâ central intrusive complex, emplaced near the base of the basalt succession on southern Ubekendt Ejland, may represent a high-level intrusion into the volcanic edifice $4-5 \mathrm{~km}$ below the surface.

The north coast of Nuussuaq also experienced alkaline igneous activity within this time interval. The alkali picrite sill at Qaarsut was presumably emplaced together with associated alkali basaltic sills and dykes intruded c. $54.5 \mathrm{Ma}$, possibly governed by faults within the Eastern Boundary Fault system. There is no obvious relation to the magmatic system on Ubekendt Ejland.

The Kanísut Member on Nuussuaq is reversely magnetized (Riisager, Riisager \& Perrin, 1999; Riisager, Riisager \& Pedersen, 2003). The whole Naqerloq Formation was erupted during the long magnetic polarity chron $\mathrm{C} 24 \mathrm{r}(57.1-54.0 \mathrm{Ma})$. The nearquiescent period at 58-56 Ma encompasses $\mathrm{C} 25 \mathrm{n}$ (57.7-57.1 Ma) (Fig. 9).

In the southern shelf area at $62^{\circ} 30^{\prime} \mathrm{N}-63^{\circ} 30^{\prime} \mathrm{N}$, five dredged lava samples are dated to the period 56.5$54 \mathrm{Ma}$; they have enriched geochemical compositions generally similar to those of the Naqerloq Formation (Larsen \& Dalhoff, 2006). Judging from the frequency 

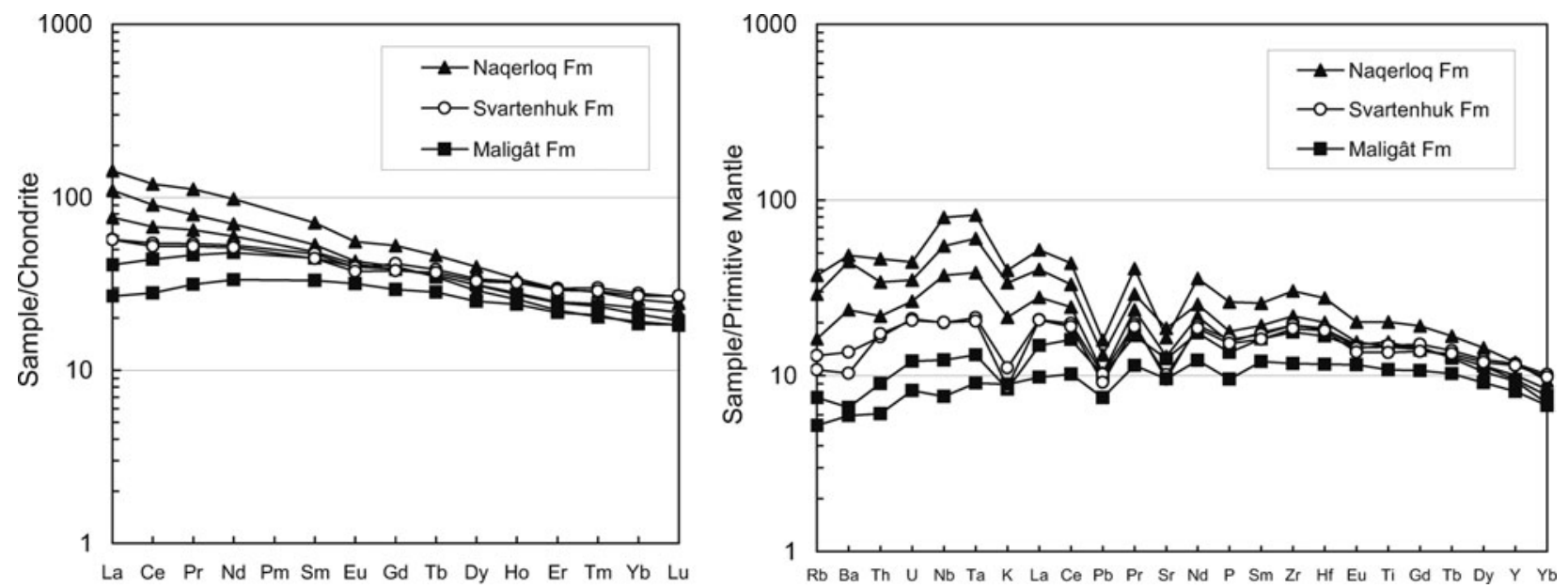

Figure 10. Rare-earth-element and multi-element patterns for representative basalt lavas from the Maligât, Svartenhuk and Naqerloq formations. In both diagrams, elements are arranged according to their degree of incompatibility in basaltic melts, with the most incompatible elements to the left. Lavas from the Maligât Formation are low in the most incompatible elements, including potassium, lavas from the Svartenhuk Formation are somewhat higher in the most incompatible elements, and lavas from the Naqerloq Formation are relatively enriched in these elements (enriched tholeiites).

of rocks with this age and composition, much of the Hecla High volcanic structure could date from this time. The contemporaneous camptonitic lamprophyres in the Søndre Isortoq area are produced by small-scale melting within a relatively thick lithosphere (Larsen et al. 2009) and suggest that lithospheric unrest extended well into the continent at the time.

\section{7.f. Early Ypresian, 54-53 Ma: Erqua Formation alkali basaltic volcanism}

The Erqua Formation is the youngest lava formation on Ubekendt Ejland. It is reversely magnetized (seven lava flows measured, P. Riisager, pers. comm. 2006) and its age of $53.47 \pm 0.52$ Ma places it very close to the end of magnetic polarity chron C24r (54.0 Ma). Its present occurrence in a small area in westernmost Ubekendt Ejland is structurally controlled, and whether it was originally more widespread or was just produced in the local volcanic system cannot be determined. In the first case, the formation may still be present in the offshore areas. It is notable that a dyke with comparable chemistry is known from the Itilli valley on Nuussuaq c. $50 \mathrm{~km}$ south of the exposures of the Erqua Formation in westernmost Ubekendt Ejland (unpub. data).

\section{7.g. Latest Ypresian c. 48 Ma: dykes in the westernmost onshore areas}

A few dykes that cut the highest parts of the volcanic succession in western Nuussuaq and western Svartenhuk Halvø have compositions that are less enriched than those of the Naqerloq Formation and more akin to those of the Svartenhuk Formation. One such dyke in westernmost Nuussuaq has an age of $48.0 \pm 2.7 \mathrm{Ma}$ and may be related to a part of the offshore volcanic succession that is younger than the Naqerloq Formation. The magnetic properties of these dykes are unknown.
In the southern shelf area at $62^{\circ} 30^{\prime} \mathrm{N}-63^{\circ} 30^{\prime} \mathrm{N}$, the ages of four dredged samples fall in the interval 53$48 \mathrm{Ma}$ (Larsen \& Dalhoff, 2006), indicating that also here the igneous activity extended into late Ypresian time.

7.h. Nine million years of onshore volcanic quiescence, c. 48 - c. 39 Ma

A period of nine million years or more followed in which there was little or no volcanic or intrusive activity in the present-day onshore area. Tectonic movements within this time interval are indicated by an angular unconformity between the lava flows of the Kanísut and Talerua members on Hareøen (Hald, 1976).

\section{7.i. Middle Eocene (Bartonian), c. 39-38 Ma: Hareøen Formation transitionally alkaline basaltic volcanism}

On Hareøen, the $38.7 \pm 0.2$ Ma lavas of the Talerua Member of the Hareøen Formation overlie the lavas of the Kanísut Member, in places with a poorly exposed sediment horizon between them (Fig. 3; Hald, 1976). Whereas the Kanísut Member is faulted and tilted 10 $20^{\circ}$, the Talerua Member is subhorizontal, attesting to tectonism in the foregoing period. No dykes with compositions similar to the Talerua Member are known. The seaward extension of the member is unconstrained.

The lavas in the lower part of the Talerua Member are normally magnetized whereas those in the upper part are reversely magnetized, and the succession is referred to magnetic polarity chrons $\mathrm{C} 18 \mathrm{n} .1 \mathrm{n}$ and $\mathrm{C} 17 \mathrm{r}$ (Schmidt et al. 2005). The Earth's polarity field was primarily normally magnetized during the period 40 $36 \mathrm{Ma}(\mathrm{C} 18 \mathrm{n}$ to $\mathrm{C} 16 \mathrm{n})$, and as the aeromagnetic pattern offshore shows large areas with normally magnetized igneous rocks (Rasmussen, 2002), it is possible that igneous activity in this period was concentrated on the 
shelf away from the onshore areas where igneous activity had essentially ceased.

\section{7.j. Latest onshore alkaline activity at c. 35 Ma (latest Eocene, Priabonian) and $c .28 \mathrm{Ma}$ (middle Oligocene)}

After middle Eocene time, only small-volume igneous activities with alkaline products are known onshore: the c. $35 \mathrm{Ma}$ alkaline lamprophyre dykes on Ubekendt Ejland (Clarke \& Pedersen, 1976; Larsen, 1981; Clarke, Muecke \& Pe-Piper, 1983) and the c. $28 \mathrm{Ma}$ Avatarpaat volcanic plug of alkali basalt west of Disko (Storey et al. 1998). Both occurrences are situated in areas where central volcanoes were developed earlier. A number of small volcanic vent agglomerates in westernmost Ubekendt Ejland (Clarke, 1973; Clarke \& Pedersen, 1976; Larsen, 1977b) appear to be younger than the lamprophyre dykes, but they are strongly altered and remain undated.

\section{Discussion}

\section{8.a. Ages of igneous rocks on the continental shelf}

As mentioned earlier, the onshore volcanic formations are considered to extend offshore. In addition, the offshore volcanic succession is expected to include younger parts than the onshore succession, because the top of the onshore succession is determined by erosion and the youngest preserved volcanic rocks occur in the westernmost areas, which are cut by faults stepping down towards the ocean (Clarke \& Pedersen, 1976).

The offshore succession has been studied in seismic sections. Skaarup $(2001,2002)$ distinguished and described five different seismic units (A-E) in the volcanic succession west of Disko, Nuussuaq and Ubekendt Ejland. The lowermost unit $\mathrm{E}$ has a chaotic internal pattern and was interpreted as subaqueous hyaloclastites. The overlying unit $\mathrm{D}$ has a variable internal pattern and is restricted to the northern study area where the Vaigat Formation occurs onshore. Seismic unit C has a mainly planar-bedded pattern that locally passes into a sigmoidal pattern, whereas unit $\mathrm{B}$ has an overall planar-bedded internal pattern and was interpreted as subaerial lava flows. Units B, C and E extend south to very near the Hellefisk-1 well. The uppermost unit A has parallel to sub-parallel internal structures and is restricted to the northern study area; it coincides with a strong normal aeromagnetic signature and must be dominantly normally magnetized.

Seismic unit D and some northern parts of unit E possibly represent, respectively, subaerial and submarine facies of the Vaigat Formation. The more extensive units $\mathrm{B}$ and $\mathrm{C}$ are likely to represent the mainly subaerial basalt formations, which will be indistinguishable seismically. As the depocentre of the Maligât Formation was in western Disko, possible equivalents of this and its age-correlatives in the Hellefisk area are the southern parts of units $\mathrm{B}$ and $\mathrm{C}$, and possible equivalents of the Svartenhuk and Naqerloq formations are the northern parts of the same units. The subaqueous unit $\mathrm{E}$ will represent the oldest formation present in any part of the area.

The youngest, normally magnetized, seismic unit A is not represented onshore. It overlies seismic unit B non-erosively, and Skaarup $(2001,2002)$ suggested it may be of C24n age. However, it may also include younger rocks unknown in the onshore areas; as shown in Figure 9 there is plenty of 'room' for additional volcanic units offshore. They could belong to any normal magnetic polarity chron from C24n $(54.0-52.6 \mathrm{Ma})$ and younger; several of the Eocene normal periods are relatively long.

In the south, the succession in the Hecla High volcanic area consists of both Paleocene and Eocene rocks, with the Paleocene probably underrepresented in the dredge samples because they are partly covered by the Eocene rocks. The undated potassium-poor volcanic rocks in the Nukik area are assumed to be Paleocene in age.

\section{8.b. Lava accumulation rates}

Storey et al. (1998) estimated magma productivities for the Vaigat and lower Maligât formations on Disko and Nuussuaq as high as $1300 \mathrm{~km}^{3} / \mathrm{Ma} / \mathrm{km}$-rift, decreasing to $200-700 \mathrm{~km}^{3} / \mathrm{Ma} / \mathrm{km}$-rift for the upper Maligât Formation. Volume estimates for the entire Nuussuaq Basin and time periods discussed here are precluded by the erosional removal of large parts of the succession. However, the preserved thicknesses and revised time intervals allow rough estimates of some accumulation and eruption rates (Table 2). The lava accumulation rate was highest, at least $2000 \mathrm{~m} \mathrm{Ma}^{-1}$, for the Vaigat Formation and declined to $c .1500 \mathrm{~m} \mathrm{Ma}^{-1}$ for the Maligât Formation and to $c .1000 \mathrm{~m} \mathrm{Ma}^{-1}$ for the Svartenhuk Formation. After the 58-56 Ma pause, the accumulation rate for the Naqerloq Formation was at least $1000 \mathrm{~m} \mathrm{Ma}^{-1}$; this is a minimum figure because the preserved succession is everywhere incomplete.

Similar accumulation rates are estimated for the lava succession in ODP Hole 915 on the SE Greenland margin for which Larsen \& Saunders (1998) estimated 11000 years between eruptions for the prebreak-up sequence and 600 years for the post-break-up picritic to basaltic sequence. In both cases the productivity maximum occurred at the time of break-up. A similar maximum at break-up was also found for the Faroes by Waagstein (1988) and for the Faroes and the East Greenland basalts by Storey, Duncan \& Tegner (2007).

\section{8.c. Magmatism and margin development}

There is general agreement between authors that the start of volcanism on the continental margins in West Greenland and Baffin Island in Paleocene time is causally connected with the onset of seafloor spreading in the Labrador Sea - Baffin Bay area around C27n time (62.5-62.2 Ma) (e.g. Chalmers \& Laursen, 1995; 
Table 2. Accumulation and eruption rates for the volcanic succession in the Nuussuaq Basin

\begin{tabular}{lcccccc}
\hline Formation & Duration & Thickness, $\mathrm{m}$ & $\mathrm{m} \mathrm{Ma}^{-1}$ & Flow thickness, $\mathrm{m}$ & Flows/Ma & Years/flow \\
\hline Naqerloq Fm & 2 my & 2000 & 1000 & 15 & 67 & 15000 \\
Pause & 2 my & 0 & & & 67 & 15000 \\
Svartenhuk Fm & 2 my & 2000 & 1000 & 15 & 100 & 10000 \\
Maligât Fm & 1 my & 1500 & 1500 & 5 & 400 & 2500 \\
Vaigat Fm & 1 my & 2000 & 2000 & 5 & \\
\hline
\end{tabular}

Naqerloq Formation - thicknesses based on Kanísut Member on Nuussuaq.

Svartenhuk Formation - thicknesses based on the succession on Svartenhuk Halvø.

Maligât Formation - thicknesses based on the succession in western Disko.

Vaigat Formation - duration based on the ages for Disko and Nuussuaq. Thickness estimated for northern

Nuussuaq. The greater thicknesses on Svartenhuk Halvø $(4 \mathrm{~km})$ and Ubekendt Ejland $(5 \mathrm{~km})$ will lead to much higher accumulation rates there if the duration is similar or even shorter, as the correlation (Fig. 3) indicates.

Saunders et al. 1997; Storey et al. 1998; Skaarup, Jackson \& Oakey, 2006; Larsen \& Pedersen, 2009; Keen, Dickie \& Dehler 2012; Oakey \& Chalmers, 2012). As discussed in Section 8.b, the magma productivities at the time of break-up were very high and similar to productivities at break-up on the East Greenland margin. The finding of rocks older than C27n on the Davis Strait High (63.35 \pm 0.74 Ma; Larsen \& Dalhoff, 2006) and the West Greenland coast $(64.0 \pm 1.3 \mathrm{Ma}$; Larsen et al. 2009) suggests there was a pre-break-up phase of magma production on the West Greenland margin analogous to that on the East Greenland margin (e.g. Saunders et al. 1997; Larsen \& Saunders, 1998; Storey, Duncan \& Tegner, 2007; Larsen et al. 2014). Considering the uncertainties on the two age determinations, however, more data are needed to prove this.

The period 58-56 Ma was magmatically quiet but tectonically active, as evidenced by the unconformity between the Svartenhuk and Naqerloq formations. The period coincides with a similar period of little or no magmatism at 57-56 Ma in East Greenland (Fig. 11) in which the pre-break-up succession was tilted and mass-flows deposited (Pedersen et al. 1997).

The early Eocene volcanism in West Greenland is ascribed to extension and melting caused by the change in spreading direction in the Labrador Sea and Baffin Bay from WSW-ENE to S-N when the NE Atlantic started opening at around $55 \mathrm{Ma}$ (Storey et al. 1998; Oakey \& Chalmers, 2012). Oakey \& Chalmers (2012) demonstrated that the change took place earlier in the south than in the north, so that the principal change happened during $\mathrm{C} 25 \mathrm{n}(57.7-57.1 \mathrm{Ma})$ in the southern Labrador Sea and during C24n (54.0-52.6 Ma) in the Nares Strait region in the north. The Nuussuaq Basin occupies an intermediate area where the direction change happened during C24r (57.1-54.0 Ma). The precise age obtained in this work for the first voluminous volcanism after the quiescent period provides evidence for when in this long interval the change took place. The Kanísut Member volcanism had just started when the tuff dated at $56.15 \pm 0.41 \mathrm{Ma}$ was deposited, c. $1 \mathrm{Ma}$ into $\mathrm{C} 24 \mathrm{r}$. The syn-break-up volcanism in East Greenland started simultaneously: the lowest part is dated at $56.1 \pm 0.5 \mathrm{Ma}$ (Storey, Duncan \& Tegner, 2007).
Storey et al. (1998) suggested that the Eocene magmas in West Greenland were generated from remnants of the Iceland plume head left stranded beneath the West Greenland lithosphere in Paleocene time. The presently known wide extent of the Eocene volcanic rocks strengthens the connection between magmatism and plate movements and, as attested to by the common chemical character of the bulk of the Eocene magmas in east and west (e.g. Hald, 1976; Larsen, 1977a; Holm, Hald \& Nielsen, 1992; Kempton et al. 2000; Larsen \& Dalhoff, 2006, 2007), it indicates that for the first time the mantle typical of the Iceland plume extended beneath the whole of the West Greenland margin as well as the East Greenland margin (Larsen et al. 2014). The scarce isotopic data for the Kanísut Member ( $\mathrm{Sr}-\mathrm{Nd}$; Holm, Hald \& Nielsen, 1992) confirm the Icelandic character of the early Eocene magmas.

The younger igneous activity on the West Greenland margin is difficult to relate to specific plate tectonic events. The $48 \mathrm{Ma}$ late dyke on Nuussuaq and the 48.5 Ma dredged sample in SW Greenland are coeval with a period of intrusive and extrusive volcanism in East Greenland (Tegner et al. 1998; Larsen et al. 2013) and with a major tectonic reorganization event in the North Atlantic around magnetic polarity chron $\mathrm{C} 21 \mathrm{r}$ (48.6-47.4 Ma) comprising changes in spreading rate and direction (Gaina, Gernigon \& Ball, 2009; Gernigon et al. 2012), but a causal connection is not clear.

Anomaly 21 is the last identifiable magnetic anomaly in the Labrador Sea (Roest \& Srivastava, 1989); from then on the slow spreading there was amagmatic. However, intermittent magmatism continued in the northern Davis Strait/Baffin Bay area. The c. 39 Ma age of the lavas of the Hareøen Formation does not correspond to any other known event in either West or East Greenland (Larsen et al. 2014). The $c$. $35 \mathrm{Ma}$ alkaline activity on Ubekendt Ejland is close in age to the time ( $c$. $33 \mathrm{Ma}$ ) when spreading in the Labrador Sea and Baffin Bay stopped altogether. It is thus most probably not related to lithospheric extension but rather to an event of regional uplift between 36 and $30 \mathrm{Ma}$ identified by Japsen, Green \& Chalmers (2005) and Japsen et al. (2006). The 27.8 Ma Avatarpaat volcanic plug west of Disko was definitely formed after the spreading ended. The generation of small-volume alkaline magmas such 


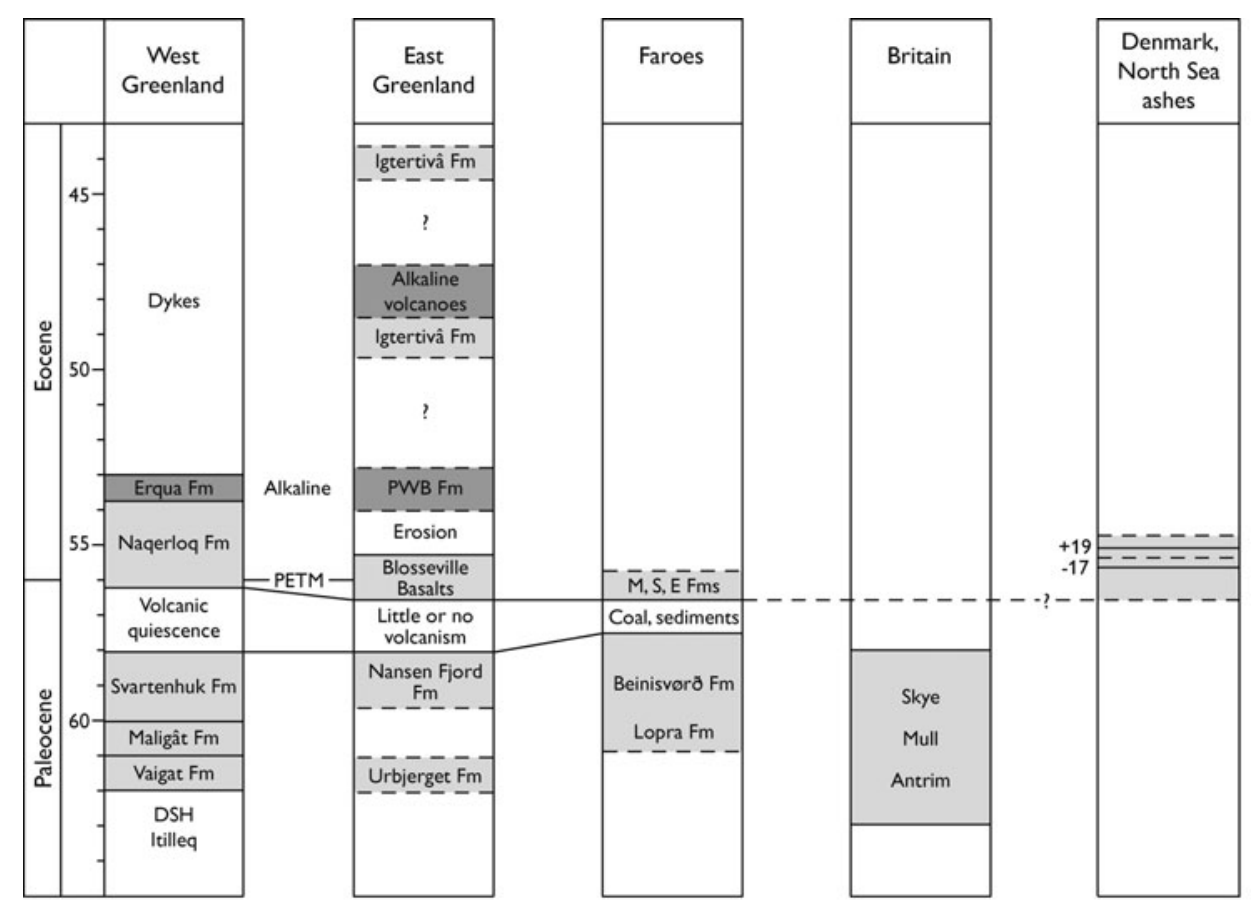

Figure 11. Age correlation of the Paleocene and early Eocene volcanic successions in West and East Greenland, the Faroes, Britain, and Denmark and the North Sea. Age relations based on this work, Storey et al. (1998), Chambers \& Pringle (2001), Hansen et al. (2002), Peate et al. (2003), Chambers, Pringle \& Parrish (2005), Larsen \& Dalhoff (2006), Storey, Duncan \& Swisher (2007), Storey, Duncan \& Tegner (2007), Larsen et al. (2009), Ganerød et al. (2010) and Larsen et al. (2013). Intrusive complexes are not shown. In West Greenland: DSH - Davis Strait High. In the Faroes stratigraphy: M - Malinstindur Formation; S - Sneis Formation; E - Enna Formation. The Danish ash layers numbered -17 and +19 are indicated. Light grey parts are tholeiitic and dark grey parts are alkaline. The Danish ash layers with negative numbers are mixed tholeiitic and alkaline.

as those of the two last magmatic events can most likely also be explained by uplift and pressure release.

\section{8.d. Event correlation to other parts of the North Atlantic Igneous Province}

The lava successions in various parts of the North Atlantic Igneous Province are juxtaposed in an age diagram in Figure 11. The oldest volcanism, pre-dating magnetochron $\mathrm{C} 27 \mathrm{n}$, is identified in West Greenland (64-63 Ma) and in the Antrim Lava Group in Ireland where the lower part has an age of $c .63 \mathrm{Ma}$ (Ganerød et al. 2010), suggesting that volcanism started nearcontemporaneously in these two parts.

As noted above, the 58-56 Ma volcanically quiescent but tectonically active period in West Greenland is contemporaneous with a similar period in East Greenland and the Faroes. At c. $58 \mathrm{Ma}$ also, the extrusion of the lava plateaus in Britain came to an end, indicating that the lack of magmatism prevailed over much or all of the North Atlantic area.

The Naqerloq Formation is contemporaneous with the voluminous 56-55 Ma syn-break-up basalts in East Greenland and the Faroes.

The Paleocene-Eocene Thermal Maximum (PETM) is an important synchronous global event near the Paleocene-Eocene boundary. The GTS 2012 places the start of the PETM at $55.85 \pm 0.12 \mathrm{Ma}$; its duration is $c$. $200 \mathrm{ka}$ (Vandenberghe, Hilgen \& Speijer, 2012). The interval would therefore be situated within the lower parts of the Naqerloq Formation and the break-upbasalts in the east, but its identification requires the presence of sediments for which $\delta^{13} \mathrm{C}$ can be measured. On Hareøen a $c .6 \mathrm{~m}$ thick interbasaltic sedimentary succession in the lower Kanísut Member could perhaps contain the PETM interval because it contains a tuff layer dated to $56.15 \pm 0.41 \mathrm{Ma}$. However, preliminary isotope analyses of the organic carbon of one horizon do not show decreased $\delta^{13} \mathrm{C}$ values. Sedimentary successions around the PETM interval are rare and widely spaced at high latitudes in the North Atlantic (e.g. on Spitsbergen; Charles et al. 2011).

The Naqerloq Formation has preserved a 55-54 Ma part of the succession that has no equivalent in East Greenland. The 55-54 Ma interval is supposed to be the stage in the opening of the North Atlantic Ocean when the major volcanic activity changed from subaerial effusive to hydroclastic explosive and hundreds of volcanic ash layers were deposited through the North Atlantic and NW Europe (Larsen, Fitton \& Pedersen, 2003). The Danish ash layer -17 and its correlative ash layer near the top of the East Greenland succession are both dated at $55.45 \pm 0.12 \mathrm{Ma}$ (Storey, Duncan \& Swisher, 2007); the equivalent level in West Greenland is situated between the lower and middle tuffs in the Kanísut Member (Fig. 11). The Danish ash layer +19 is 0.5 Ma younger than ash layer -17 (Chambers et al. 2003), i.e. close to $55.0 \mathrm{Ma}$, so that the positive ash series in Denmark (layers +1 to +140 ) is contemporaneous with the middle to upper part of the Kanísut 
Member. It remains to be seen if easterly winds during some eruptions could have blown ashes westwards instead of eastwards.

\section{Conclusions}

The 27 new radiometric ages of Tertiary igneous rocks from the Nuussuaq Basin and the Hellefisk-1 well in West Greenland have led to the establishment of a unified stratigraphic scheme for the volcanic successions throughout the basin.

The 62.5-61 Ma picritic Vaigat Formation in the Nuussuaq Basin extended N-S for $260 \mathrm{~km}$; at the time of eruption the distance between Disko and the picrites at Cape Dyer on Baffin Island was $180 \mathrm{~km}$, and the picritic volcanism may have extended over the whole basinal area between the Nuussuaq Basin and Baffin Island.

The 61-60 Ma basaltic Maligât Formation on Disko and Nuussuaq is contemporaneous with the volcanic succession in the Hellefisk-1 well and is older than most of the basalts on westernmost Nuussuaq, Ubekendt Ejland and Svartenhuk Halvø. The younger basalts comprise the 60-58 Ma Svartenhuk Formation, the 56$54 \mathrm{Ma}$ Naqerloq Formation and the 53.7 Ma Erqua Formation. Dykes on Disko and Nuussuaq show that lavas of the Svartenhuk and Naqerloq formations originally extended at least $150 \mathrm{~km}$ further south than their present extension.

Younger volcanic ages are widely spaced at c. $48 \mathrm{Ma}$, c. $39 \mathrm{Ma}$, c. $35 \mathrm{Ma}$ and c. $28 \mathrm{Ma}$. The true durations of these late episodes are unknown.

Lava accumulation rates peaked during the emplacement of the Vaigat Formation $\left(\geq 2000 \mathrm{~m} \mathrm{Ma}^{-1}\right)$ and declined during the rest of Paleocene time (Maligât and Svartenhuk formations, 1500-1000 $\mathrm{m} \mathrm{Ma}^{-1}$ ); the Eocene Naqerloq Formation accumulated at a minimum at the same rate as the Svartenhuk Formation.

At 58-56 Ma, there was a c. 2 Ma period with little or no magma production but with some tectonism. In this period, leading up to the Paleocene-Eocene transition at $56 \mathrm{Ma}$, a significant change in the mantle sources took place, and the Paleocene and Eocene tholeiitic basalts are distinguishable chemically. The concomitant change in spreading direction, which happened earlier in southern Greenland (C25n) than in northern Greenland (C24n) (Oakey \& Chalmers, 2012), happened in the Nuussuaq Basin close to $1 \mathrm{Ma}$ into C24r.

The volcanic succession on Ubekendt Ejland contains a much larger proportion of acid and alkaline lavas and tuffs than the other areas of the Nuussuaq Basin, indicating that a large central volcanic complex was developed there already in Paleocene time. Ubekendt Ejland hosts the only central intrusion in the Nuussuaq Basin, the Sarqâta qáqâ gabbro-granophyre complex, which is dated here at 56-55 Ma.

The volcanic succession in the offshore area between $67^{\circ} 30^{\prime} \mathrm{N}$ and $73^{\circ} \mathrm{N}$ is expected to comprise the Vaigat Formation over large areas, the Maligât Formation in the southern part, the Svartenhuk and Naqerloq formations mainly in the northern part, and probably still younger Eocene lavas and perhaps intrusions west of Nuussuaq and Ubekendt Ejland.

Some pre-break-up volcanism took place at 64 $63 \mathrm{Ma}$ in the southern area around $66^{\circ} 30^{\prime} \mathrm{N}$.

The major volcanic episodes in West Greenland are contemporaneous with events elsewhere in the North Atlantic. In particular, the quiescent period at 58$56 \mathrm{Ma}$ correlates with a similar period in East Greenland and the Faroes, and the volcanism of the Naqerloq Formation started near-simultaneously with the Eocene Blosseville Kyst volcanism. The lowest part of the Naqerloq Formation may contain the PETM interval, and the middle to upper part of the Naqerloq Formation is contemporaneous with the cataclysmic eruptions of volcanic ash in the North Atlantic.

Eocene lavas in the Nuussuaq Basin and in the Hecla High volcanic centre on the SW Greenland shelf have a geochemical character similar to that of the Blosseville Kyst basalts, and in early Eocene time mantle typical of the Iceland plume seems to have extended beneath the whole West Greenland margin as well as the central East Greenland margin.

\section{Supplementary material}

To view supplementary material for this article, please visit http://dx.doi.org/10.1017/S0016756815000515.

Acknowledgements. We thank GEUS and the Arctic Station in Qeqertarsuaq/Godhavn for providing support during field work. Stefan Bernstein organized the field work on Ubekendt Ejland. Lara Heister provided some unpublished reconnaissance ages for samples from the Eocene part of the succession. Anthony Koppers and Dan Miggins recalculated the ${ }^{40} \mathrm{Ar}-{ }^{39} \mathrm{Ar}$ ages to the new (2012) age for the FCT monitor. The manuscript was improved by comments from Jim Chalmers, Gunver Krarup Pedersen and two anonymous reviewers. Publication was authorized by the Geological Survey of Denmark and Greenland.

\section{References}

Beckinsale, R. D., Thompson, R. N. \& Durham, J. J. 1974. Petrogenetic significance of initial ${ }^{87} \mathrm{Sr} /{ }^{86} \mathrm{Sr}$ ratios in the North Atlantic Tertiary Igneous Province in the light of $\mathrm{Rb}-\mathrm{Sr}, \mathrm{K}-\mathrm{Ar}$, and ${ }^{18} \mathrm{O}$-abundance studies of the Sarqâta qáqâ intrusive complex, Ubekendt Ejland, West Greenland. Journal of Petrology 15, 525-38.

Brown, D. J., Holohan, E. P. \& BeLL, B. 2009. Sedimentary and volcano-tectonic processes in the British Paleocene Igneous Province: a review. Geological Magazine 146, 326-52.

Chalmers, J. A. \& LAURSEN, K. H. 1995. Labrador Sea: the extent of continental crust and the timing of the start of sea-floor spreading. Marine and Petroleum Geology 12, 205-17.

Chalmers, J. A. \& Pulvertaft, T. C. R. 2001. Development of the continental margins of the Labrador Sea: a review. In Non-Volcanic Rifting of Continental Margins: A Comparison of Evidence from Land and Sea (eds R. C. L. Wilson, R. B. Whitmarsh, B. Taylor \& 
N. Froitzheim), pp. 77-105. Geological Society of London, Special Publication no. 187.

Chambers, L. M. \& Pringle, M. S. 2001. Age and duration of activity at the Isle of Mull Tertiary igneous centre, Scotland, and confirmation of the existence of subchrons during Anomaly 26r. Earth and Planetary Science Letters 193, 333-45.

Chambers, L. M., Pringle, M., Fitton, G., Larsen, L. M., PEDERSEN, A. K. \& PARRISH, R. 2003. Recalibration of the Palaeocene-Eocene boundary (P-E) using high precision $\mathrm{U}-\mathrm{Pb}$ and $\mathrm{Ar}-\mathrm{Ar}$ isotopic dating. Abstract, $E G S-A G U-E U G$ Joint Assembly, Nice, $6^{\text {th }}-11^{\text {th }}$ April 2003.

Chambers, L. M., Pringle, M. S. \& Parrish, R. R. 2005. Rapid formation of the Small Isles Tertiary centre constrained by precise ${ }^{40} \mathrm{Ar} /{ }^{39} \mathrm{Ar}$ and $\mathrm{U}-\mathrm{Pb}$ ages. Lithos 79, 367-84.

Charles, A. J., Condon, D. J., Harding, I. C., PÄlike, H., Marshall, J. E. A., CuI, Y., Kump, L. \& Croudace, I. W. 2011. Constraints on the numerical age of the Paleocene-Eocene Boundary. Geochemistry, Geophysics, Geosystems 12(6), doi: 10.1029/2010GC003426, $19 \mathrm{pp}$.

Clarke, D. B. 1973. New mapping in the western part of Ubekendt Ejland. Rapport Grønlands Geologiske Undersøgelse 53, 5-9.

Clarke, D. B., Muecke, G. K. \& Pe-Piper, G. 1983. The lamprophyres of Ubekendt Ejland, West Greenland: products of renewed partial melting or extreme differentiation? Contributions to Mineralogy and Petrology 83, $117-27$.

Clarke, D. B. \& Pedersen, A. K. 1976. Tertiary volcanic province of West Greenland. In Geology of Greenland (eds A. Escher \& W. S. Watt), pp. 364-85. Copenhagen: Geological Survey of Greenland.

Clarke, D. B. \& Upton, B. G. J. 1971. Tertiary basalts of Baffin Island: field relations and tectonic setting. Canadian Journal of Earth Sciences 8, 248-58.

Dalhoff, F., Larsen, L. M., Ineson, J., Stouge, S., BoJESEN-Koefoed, J., LASSEN, S., KuIJPERS, J., RASMussen, J. A. \& NøHR-HANSEN, H. 2006. Continental crust in the Davis Strait: new evidence from seabed sampling. Geological Survey of Denmark and Greenland Bulletin 10, 33-6.

Dam, G., Pedersen, G. K., Sønderholm, M. S., MidtgaARd, H. H., LARSEN, L. M., Nøhr-Hansen, H. \& Pedersen, A. K. 2009. Lithostratigraphy of the Cretaceous-Paleocene Nuussuaq Group, Nuussuaq Basin, West Greenland. Geological Survey of Denmark and Greenland Bulletin 19, 1-171.

Deutsch, E. R., Kristjansson, L. G. \& MaY, B. T. 1971. Remanent magnetism of lower Tertiary lavas on Baffin Island. Canadian Journal of Earth Sciences 8, 1542-52.

DRESCHER, F. K. 1933. Zur Kenntnis der Peridotits von Kaersut (Grönland) und seines Ganggefolges. Zeitschrift für Kristallographie, Mineralogie und Petrographie 43(45), 207-70.

DREVER, H. I. 1958. Geological results of four expeditions to Ubekendt Ejland, West Greenland. Arctic 11, 199-210.

DREVER, H. I. \& GAME, P. M. 1948. The geology of Ubekendt Ejland, West Greenland, part I, a preliminary review. Meddelelser om Grønland 134(8), 1-35.

Eldholm, O. \& GRUE, K. 1994. North Atlantic volcanic margins: dimensions and production rates. Journal of Geophysical Research 99(B2), 2955-68.

Foulger, G. R. \& ANDERSON, D. L. 2005. A cool model for the Iceland hotspot. Journal of Volcanology and Geothermal Research 141, 1-22.
Funck, T., GOHL, K., DAMM, V. \& HeYde, I. 2012. Tectonic evolution of southern Baffin Bay and Davis Strait: results from a seismic refraction transect between Canada and Greenland. Journal of Geophysical Research 117, B04107, doi: 10.1029/2011JB009110, 24 pp.

FunCK, T., JACKSON, H. R., LOUDEN, K. E. \& KLINGELHÖFER, F. 2007. Seismic study of the transformrifted margin in Davis Strait between Baffin Island (Canada) and Greenland: what happens when a plume meets a transform. Journal of Geophysical Research 112, B04402, doi: 10.1029/2006JB004308, $22 \mathrm{pp}$.

Gaina, C., Gernigon, L. \& BALl, P. 2009. PalaeoceneRecent plate boundaries in the NE Atlantic and the formation of the Jan Mayen microcontinent. Journal of the Geological Society, London 166, 601-16.

Ganerød, M., SMEthurst, M. A., TORSVIK, T. H., Prestvik, T., Rousse, S., McKenna, C., van HinsBERGEN, D. J. J. \& HENDRICKS, B. W. H. 2010. The North Atlantic Igneous Province reconstructed and its relation to the Plume Generation Zone: the Antrim Lava Group revisited. Geophysical Journal International 182, 183-202.

Geoffroy, L., Callot, J.-P., Scaillet, S., Skuce, A., GÉlard, J. P., Ravilly, M., ANGelier, J., Bonin, B., Perrot, K. \& LePvrier, C. 2001. Southeast Baffin volcanic margin and the North American-Greenland plate separation. Tectonics 20, 566-84.

Gernigon, L., Gaina, C., Olesen, O., Ball, P. J., PéronPINVIDIC, G. \& YAMASAKI, T. 2012. The Norway Basin revisited: from continental breakup to spreading ridge. Marine and Petroleum Geology 35, 1-19.

Gradstein, F. M., OGG, J. G., Schmitz, M. \& OGG, G. (eds) 2012. The Geologic Time Scale 2012. Amsterdam: Elsevier.

GREgersen, U. \& Bidstrup, T. 2008. Structures and hydrocarbon prospectivity in the northern Davis Strait area, offshore West Greenland. Petroleum Geoscience 14, 151-66.

HALD, N. 1976. Early Tertiary flood basalts from Hareøen and western Nûgssuaq, West Greenland. Bulletin Grønlands Geologiske Undersøgelse 120, 1-36.

HALD, N. \& LARSEN, J. G. 1987. Early Tertiary, low potassium tholeiites from exploration wells on the West Greenland shelf. Rapport Grønlands Geologiske Undersøgelse 136, 1-25.

Hald, N. \& Pedersen, A. K. 1975. Lithostratigraphy of the Early Tertiary volcanic rocks of central West Greenland. Rapport Grønlands Geologiske Undersøgelse 69, 1724.

Hansen, H., Pedersen, A. K., Duncan, R. A., Bird, D. K., BROOKS, C. K., FAWCETT, J. J., GitTins, J., GORTON, M. \& O'DAY, P. 2002. Volcanic stratigraphy of the southern Prinsen af Wales Bjerge region, East Greenland. In The North Atlantic Igneous Province: Stratigraphy, Tectonics, Volcanic and Magmatic Processes (eds D. W. Jolley \& B. R. Bell), pp. 157-81. Geological Society of London, Special Publication no. 197.

Henderson, G., Rosenkrantz, A. \& Schiener, E. J. 1976. Cretaceous-Tertiary sedimentary rocks of West Greenland. In Geology of Greenland (eds A. Escher \& W. S. Watt), pp. 340-62. Copenhagen: Geological Survey of Greenland.

Henderson, G., Schiener, E. J., Risum, J. B., Croxton, C. A. \& Andersen, B. B. 1981. The West Greenland Basin. In Geology of the North Atlantic Borderlands (ed. J. W. Kerr), pp. 399-428. Canadian Society of Petroleum Geologists, Memoir no. 7. 
Henriksen, N., Higgins, A. K., Kalsbeek, F. \& Pulvertaft, T. C. R. 2009. Greenland from Archaean to Quaternary. Descriptive text to the 1995 Geological Map of Greenland 1:2 $500000.2^{\text {nd }}$ edition. Geological Survey of Denmark and Greenland Bulletin 18, 1-126.

Holm, P. M., Hald, N. \& Nielsen, T. F. D. 1992. Contrasts in composition and evolution of Tertiary CFBs in West and East Greenland: tectonic effects during the establishment of the Icelandic mantle plume. In Magmatism and the Causes of Continental Break-up (eds B. C. Storey, T. Alabaster \& R. J. Pankhurst), pp. 34962. Geological Society of London, Special Publication no. 68.

Japsen, P., Bonow, J. M., Green, P. F., Chalmers, J. A. \& LIDMAR-BERGSTRÖM, K. 2006. Elevated, passive continental margins: long-term highs or Neogene uplifts? New evidence from Greenland. Earth and Planetary Science Letters 248, 315-24.

JAPSEN, P., GREEN, P. F. \& ChALMERS, J. A. 2005. Separation of Palaeogene and Neogene uplift on Nuussuaq, West Greenland. Journal of the Geological Society, London 162, 299-314.

KeEN, C. E., Dickie, K. \& Dehler, S. A. 2012. The volcanic margins of the northern Labrador Sea: insights to the rifting process. Tectonics 31, doi: 10.1029/2011TC002985, $13 \mathrm{pp}$.

Kempton, P. D., Fitton, J. G., Saunders, A. D., Nowell, G. M., TAYlor, R. N., HARdarson, B. S. \& PeARson, G. 2000. The Iceland plume in space and time: a Sr-Nd$\mathrm{Pb}-\mathrm{Hf}$ study of the North Atlantic rifted margin. Earth and Planetary Science Letters 177, 255-71.

KOPPERS, A. K. 2002. ArArCALC - software for ${ }^{40} \mathrm{Ar} /{ }^{39} \mathrm{Ar}$ age calculations. Computers \& Geosciences 28, 605-19.

Kuiper, K. F., Deino, A., Hilgen, F. J., Krijgsman, W., RENNE, P. R. \& WiJBRANS, J. R. 2008. Synchronizing rock clocks of Earth history. Science 320, 500-4.

Larsen, H. C. \& SAUnders, A. D. 1998. Tectonism and volcanism at the Southeast Greenland rifted margin: a record of plume impact and later continental rupture. In Proceedings of the Ocean Drilling Program, Scientific Results, vol. 152 (eds A. D. Saunders, H. C. Larsen \& S. H. Wise), pp. 503-34. College Station, TX.

LARSEN, J. G. 1977a. Transition from low potassium olivine tholeiites to alkali basalts on Ubekendt Ejland. Meddelelser om Grønland 200(1), 1-42.

LARSEN, J. G. 1977b. Field work on Ubekendt Ejland in the Tertiary basalt province of West Greenland 1971 and 1973. Rapport Grønlands Geologiske Undersøgelse 79, $35-44$.

LARSEN, J. G. 1981. Medium pressure crystallisation of a monchiquitic magma - evidence from megacrysts of Drever's block, Ubekendt Ejland, West Greenland. Lithos 14, 241-62.

LARSEN, J. G. 1983. Geological Map of Greenland, 1:100 000, Igdlorssuit 71 V.1 Syd. Copenhagen: Geological Survey of Denmark and Greenland.

LARSEN, J. G. \& GROCOTT, J. 1991. Geological Map of Greenland, 1:100 000, Svartenhuk 71 V.1 Nord. Copenhagen: Geological Survey of Denmark and Greenland.

LARSEN, J. G. \& PULVERTAFT, T. C. R. 2000. The structure of the Cretaceous-Palaeogene sedimentary-volcanic area of Svartenhuk Halvø, central West Greenland. Geology of Greenland Survey Bulletin 188, 1-40.

LARSEN, L. M. 2006. Mesozoic to Palaeogene dyke swarms in West Greenland and their significance for the formation of the Labrador Sea and the Davis Strait. Danmarks og Grønlands Geologiske Undersøgelse Rapport 34, 1-69.
LARSEN, L. M. \& DALhOFF, F. 2006. Composition, age, and geological and geotectonic significance of igneous rocks dredged from the northern Labrador Sea and the Davis Strait. Danmarks og Grønlands Geologiske Undersøgelse Rapport 43, 1-51.

LARSEN, L. M. \& DALhOFF, F. 2007. Composition and significance of igneous rocks dredged in 2006 from the northern Labrador Sea and the Davis Strait. Danmarks og Grønlands Geologiske Undersøgelse Rapport 67, 129.

Larsen, L. M., Fitton, J. G. \& Pedersen, A. K. 2003. Palaeogene volcanic ash layers in the Danish Basin: compositions and source areas in the North Atlantic Igneous Province. Lithos 71, 47-80.

Larsen, L. M., Heaman, L. M., Creaser, R. A., Duncan, A. R., FREI, R. \& HUTCHISON, M. 2009. Tectonomagmatic events during stretching and basin formation in the Labrador Sea and the Davis Strait: evidence from age and composition of Mesozoic to Palaeogene dyke swarms in West Greenland. Journal of the Geological Society, London 166, 999-1012.

Larsen, L. M. \& Pedersen, A. K. 2009. Petrology of the Paleocene picrites and flood basalts on Disko and Nuussuaq, West Greenland. Journal of Petrology 50, 1667711.

Larsen, L. M., Pedersen, A. K., Sørensen, E. V., Watt, W. S. \& DunCAN, R. A. 2013. Stratigraphy and age of the Eocene Igtertivâ Formation basalts, alkaline pebbles and sediments of the Kap Dalton Group in the graben at Kap Dalton, East Greenland. Bulletin of the Geological Society of Denmark 61, 1-18.

Larsen, L. M., Pedersen, A. K., Tegner, C. \& Duncan, R. A. 2014. Eocene to Miocene igneous activity in northeastern Greenland: northward younging of magmatism along the East Greenland margin. Journal of the Geological Society, London 171, 539-53.

Larsen, L. M., ReX, D. C., Watt, W. S. \& Guise, P. G. 1999. ${ }^{40} \mathrm{Ar}-{ }^{39} \mathrm{Ar}$ dating of alkali basaltic dykes along the south-west coast of Greenland: Cretaceous and Tertiary igneous activity along the eastern margin of the Labrador Sea. Geology of Greenland Survey Bulletin 184, 19-29.

LUNDIN, E. R. \& DoRÉ, A. G. 2005. NE Atlantic break-up: a re-examination of the Iceland mantle plume model and the Atlantic - Arctic linkage. In Petroleum Geology: North-West Europe and Global Perspectives - Proceedings of the $6^{\text {th }}$ Petroleum Geology Conference (eds A. G. Doré \& B. A. Vining), pp. 739-54. London: The Geological Society.

Maclean, B., FAlconer, R. K. H. \& Clarke, D. B. 1978. Tertiary basalts of western Davis Strait: bedrock core samples and geophysical data. Canadian Journal of Earth Sciences 15, 773-80.

Min, K., MundiL, R., RENNE, P. R. \& LudwiG, K. R. 2000. A test for systematic errors in ${ }^{40} \mathrm{Ar} /{ }^{39} \mathrm{Ar}$ geochronology through comparison with $\mathrm{U} / \mathrm{Pb}$ analysis of a 1.1 Ga rhyolite. Geochimica et Cosmochimica Acta 64, 73-98.

Neuhoff, P. S., Rogers, K. L., Stannius, L. S., Bird, D. K. \& Pedersen, A. K. 2006. Regional very low-grade metamorphism of basaltic lavas, Disko-Nuussuaq region, West Greenland. Lithos 92, 33-54.

NøHR-HANSEN, H. 2003. Dinoflagellate cyst stratigraphy of the Palaeogene strata from the Hellefisk-1, Ikermiut1, Kangâmiut-1, Nukik-1, Nukik-2 and Qulleq-1 wells, offshore West Greenland. Marine and Petroleum Geo$\log y \mathbf{2 0}, 987-1016$. 
OAKEY, G. N. \& Chalmers, J. A. 2012. A new model for the Paleogene motion of Greenland relative to North America: plate reconstructions of the Davis Strait and Nares Strait regions between Canada and Greenland. Journal of Geophysical Research 117, B10401, doi: 10.1029/2011JB008942, 28 pp.

PARROTT, R. J. E. \& REYNOLDS, P. H. 1975. Argon-40/argon39 geochronology: age determinations of basalts from the Labrador Sea area. Abstracts, Geological Society of America 7, 835.

Peate, D. W., BAKeR, J. A., Blichert-Toft, J., Hilton, D. R., Storey, M., Kent, A. J. R., BROOKS, C. K., HANSEN, H., Pedersen, A. K. \& Duncan, R. A. 2003. The Prinsen af Wales Bjerge Formation lavas, East Greenland: the transition from tholeiitic to alkalic magmatism during Palaeogene continental break-up. Journal of Petrology 44, 279-304.

PEDERSEN, A. K. 1985. Lithostratigraphy of the Tertiary Vaigat Formation on Disko, central West Greenland. Rapport Grønlands Geologiske Undersøgelse 124, 130.

Pedersen, A. K., Larsen, L. M. \& Dueholm, K. S. 1993. Geological Section Along the South Coast of Nuussuaq, Central West Greenland. 1:20 000 Coloured Geological Sheet. Copenhagen: Geological Survey of Greenland.

Pedersen, A. K., LARSEN, L. M. \& Dueholm, K. S. 2002. Geological Section Along the North Side of the Aaffarsuaq Valley and Central Nuussuaq, Central West Greenland. 1:20 000 Coloured Geological Sheet. Copenhagen: Geological Survey of Denmark and Greenland.

Pedersen, A. K., Larsen, L. M., Pedersen, G. K. \& Duenolm, K. S. 2005. Geological Section Across North Central Disko from Nordfjord to Pingu, Central West Greenland. 1:20 000 Coloured Geological Sheet. Copenhagen: Geological Survey of Denmark and Greenland.

Pedersen, A. K., Larsen, L. M., Pedersen, G. K., HeInesen, M. V. \& Dueholm, K. S. 2003. Geological Section Along the South and South-West Coast of Disko, Central West Greenland. 1:20 000 Coloured Geological Sheet. Copenhagen: Geological Survey of Denmark and Greenland.

Pedersen, A. K., LARSEN, L. M., RiISAger, P. \& Dueholm, K. S. 2002. Rates of volcanic deposition, facies changes and movements in a dynamic basin: the Nuussuaq Basin, West Greenland, around the $\mathrm{C} 27 \mathrm{n}-\mathrm{C} 26 \mathrm{r}$ transition. In The North Atlantic Igneous Province: Stratigraphy, Tectonics, Volcanic and Magmatic Processes (eds D. W. Jolley \& B. R. Bell), pp. 157-81. Geological Society of London, Special Publication no. 197

Pedersen, A. K., Watt, M., Watt, W. S. \& LARSEN, L. M. 1997. Structure and stratigraphy of the Early Tertiary basalts of the Blosseville Kyst, East Greenland. Journal of the Geological Society, London 154, 56570.

RASMUSSEN, T. M. 2002. Aeromagnetic survey in central West Greenland: Project Aeromag 2001. Geology of Greenland Survey Bulletin 191, 67-72.

RiISAger, J., RiISAger, P. \& Pedersen, A. K. 2003. Paleomagnetism of large igneous provinces: casestudy from West Greenland, North Atlantic igneous province. Earth and Planetary Science Letters 214, 40925.

RIISAgER, J., RiISAgER, P. \& PERRIN, M. 1999. Palaeodirectional and palaeointensity results of Paleocene and Eocene basalts from West Greenland. Bulletin Geological Society of Denmark 46, 69-78.

RIISAGER, P. \& ABRAHAMSEN, N. 1999. Magnetostratigraphy of Paleocene basalts from the Vaigat Formation of West Greenland. Geophysical Journal International 137, 774-82.

Roest, W. R. \& SRIVASTAVA, S. P. 1989. Sea-floor spreading in the Labrador Sea: a new reconstruction. Geology 17, $1000-3$.

Saunders, A. D., Fitton, J. G., Kerr, A. C., Norry, M. J. \& Kent, R. W. 1997. The North Atlantic Igneous Province. In Large Igneous Provinces (eds J. J. Mahoney \& M. L. Coffin), pp. 45-93. American Geophysical Union, Geophysical Monograph vol. 100. Washington, DC, USA.

SCHMIDT, A. G., RIISAGER, P., ABRAHAMSEN, N., RIISAGER, J., Pedersen, A. K. \& VAN Der VoO, R. 2005. Palaeomagnetism of the Eocene Talerua Member lavas on Hareøen, West Greenland. Bulletin of the Geological Society of Denmark 52, 27-38.

SCHMITZ, M. D. 2012. Radiogenic isotope geochronology. In The Geologic Time Scale 2012 (eds F. M. Gradstein, J. G. Ogg, M. Schmitz \& G. Ogg), pp. 115-26. Amsterdam: Elsevier.

SKAARUP, N. 2001. Offshore volcanic rocks in Baffin Bay. A seismic interpretation of the structures and development of the Palaeogene offshore volcanic rocks in West Greenland and on the Baffin Island margin, eastern Canada. Danmarks og Grønlands Geologiske Undersøgelse Rapport 117, 1-157.

SKAARUP, N. 2002. Evidence for continental crust in the offshore Palaeogene volcanic province, central West Greenland. Geology of Greenland Survey Bulletin 191, 97102.

SKAARUP, N., JACKSON, H. R. \& OAKEY, G. 2006. Margin segmentation of Baffin Bay/Davis Strait, eastern Canada based on seismic reflection and potential field data. Marine and Petroleum Geology 23, 127-44.

SøRENSEN, A. B. 2006. Stratigraphy, structure and petroleum potential of the Lady Franklin and Maniitsoq Basins, offshore southern West Greenland. Petroleum Geoscience 12, 221-34.

Starkey, N. A., Stuart, F. M., Ellam, R. M., Fitton, J. G., BASU, S. \& LARSEN, L. M. 2009. Helium isotopes in early Iceland plume picrites: constraints on the composition of high ${ }^{3} \mathrm{He} /{ }^{4} \mathrm{He}$ mantle. Earth and Planetary Science Letters 277, 91-100.

Storey, M., Duncan, R. A., Pedersen, A. K., Larsen, L. M. \& LARSEN, H. C. $1998 .{ }^{40} \mathrm{Ar} /{ }^{39} \mathrm{Ar}$ geochronology of the West Greenland Tertiary volcanic province. Earth and Planetary Science Letters 160, 569-86.

Storey, M., DunCAN, R. A. \& SWISHER, C. C. 2007. Paleocene-Eocene thermal maximum and the opening of the Northeast Atlantic. Science 316, 587-9.

Storey, M., DunCAN, R. A. \& Tegner, C. 2007. Timing and duration of volcanism in the North Atlantic Igneous Province: implications for geodynamics and links to the Iceland hotspot. Chemical Geology 241, 264-81.

Tegner, C., DunCAN, R. A., Bernstein, S., BRoOKS, C. K., BIRD, D. \& STOREY, M. 1998. ${ }^{40} \mathrm{Ar}-{ }^{39}$ Ar geochronology of Tertiary mafic intrusions along the East Greenland rifted margin: relation to flood basalts and the Iceland hotspot track. Earth and Planetary Science Letters 156, $75-88$.

Upton, B. G. J. 1988. History of Tertiary igneous activity in the N Atlantic borderlands. In Early Tertiary Volcanism and the Opening of the NE Atlantic (eds A. C. Morton \& L. M. Parson), pp. 429-53. Geological Society of London, Special Publication no. 39.

Vandenberghe, N., Hilgen, F. J. \& Speijer, R. P. 2012. The Paleogene period. In The Geologic Time Scale 2012 (eds F. M. Gradstein, J. G. Ogg, M. Schmitz \& G. Ogg), pp. 855-921. Amsterdam: Elsevier. 
WAAGSTEIN, R. 1988. Structure, composition and age of the Faeroe basalt plateau. In Early Tertiary Volcanism and the Opening of the NE Atlantic (eds A. C. Morton \& L. M. Parson), pp. 225-38. Geological Society of London, Special Publication no. 39.

WhitTAKeR, R. C. 1996. A preliminary seismic interpretation of an area with extensive Tertiary basalts offshore central West Greenland. Bulletin Grønlands Geologiske Undersøgelse 172, 28-31.
Williamson, M-C., Villeneuve, M. E., LARSen, L. M., JACKSON, H. R., OAKEY, G. N. \& MACLEAN, B. 2001. Age and petrology of offshore basalts from the Southeast Baffin Island Shelf, Davis Strait, and western Greenland continental margin. Geological Association of Canada / Mineralogical Association of Canada Joint Annual Meeting, St John's, Newfoundland, Canada, May 27-30, 2001. Abstracts Volume 26, p. 162. 